CENTRE for ECONOMIC

$P$ E R F O R M A N C E

CEP Discussion Paper No 713

January 2006

\title{
Union Free-Riding in Britain and New Zealand
}

\author{
Alex Bryson
}

The Leverhulme Trust

Registered Charity No: 288371

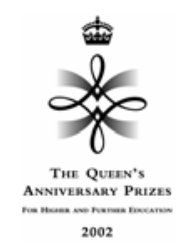




\begin{abstract}
The percentage of workers who choose not to join the union available to them at their workplace has been rising in Britain and New Zealand. Social custom, union instrumentality, the fixed costs of joining, employee perceptions of management attitudes to unionization and employee problems at work all influence the propensity to free-ride. Ideological convictions regarding the role of unions also play some role, as do private excludable goods. There is little indication of employer-inspired policies substituting for unionization where unions are already present. Having accounted for all these factors, free-riding remains more common in New Zealand than in Britain.
\end{abstract}

Key words: Free-riding; trade union; New Zealand; Britain JEL classification: J50

This paper is produced under the 'Future of Trade Unions in Modern Britain' Programme supported by the Leverhulme Trust. The Centre for Economic Performance acknowledges with thanks, the generosity of the Trust. For more information concerning this Programme please e-mail future_of_unions@Ise.ac.uk

\title{
Acknowledgements
}

I thank Peter Haynes for assistance and comments and Harvard Law School and NBER for financial support.

Alex Bryson is a Principal Research Fellow at the Policy Studies Institute, London and Wertheim Fellow, Harvard Law School. Email: a.bryson@psi.org.uk.

Published by

Centre for Economic Performance

London School of Economics and Political Science

Houghton Street

London WC2A 2AE

All rights reserved. No part of this publication may be reproduced, stored in a retrieval system or transmitted in any form or by any means without the prior permission in writing of the publisher nor be issued to the public or circulated in any form other than that in which it is published.

Requests for permission to reproduce any article or part of the Working Paper should be sent to the editor at the above address.

(C) Alex Bryson, submitted 2006

ISBN 0753019124 


\section{Introduction}

Since the early 1990s, compulsory union membership - the 'closed shop' - has been unlawful in Britain and New Zealand, so that joining a union has become a matter of individual choice. Membership density has declined in unionized workplaces in both countries since the legislative change, indicating a rise in 'free-riding'. In both countries, although there is evidence of free-riding prior to the legislative changes, the practice increased markedly in the 1990s (Table 1 presents data for Britain; Haynes and Boxall, 2004 discuss trends in New Zealand).

Free-riding has become a serious problem for trade unions since, as voluntary membership organisations, they are reliant on union subscriptions for their financial survival. Yet many of the services unions provide, such as higher wages and better terms and conditions, are public or collective goods available to members and non-members alike, creating an incentive for individuals to opt out of union membership, that is, to free-ride.

The policy response to increased free-riding from the governments in both countries has been very different. In Britain, concern that employer opposition to unions denies workers their rights to organise has resulted in statutory support for union recognition where a majority of workers in a bargaining unit wish for it (Wood, Moore, and Ewing 2003), but there is little concern about free-riding where a union is already established. In New Zealand, on the other hand, parliament legislated in 2004 to allow for agency fees in labormanagement contracts, potentially requiring non-members to pay for the service they receive from unions, even if they choose to remain non-members - what is often referred to as an 'agency shop' (Haynes and Boxall 2004). ${ }^{1}$

This paper uses unique comparable data for Britain and New Zealand to explore the reasons given for free-riding, and to identify how free-riders differ from union members. We find social custom, union instrumentality, the fixed costs of joining, employee perceptions of management attitudes to unionization and employee problems at work all influence the propensity to free-ride. Ideological convictions regarding the role of unions also play some role, as do private excludable goods. There is little indication of employer-inspired policies substituting for unionization where unions are already present.

We begin by outlining the theory informing our understanding of union free-riding. We then introduce the data, establish the incidence of free-riding in both countries and describe the reasons individuals give for not joining a union when one is available to them. Multivariate analyses are used to isolate the factors associated with free-riding, comparing and contrasting those factors across the two countries. The conclusions discuss the implications of the analysis for unions.

\section{Theory and Evidence on Union Free-Riding}

Since the wages, terms and conditions arising from union collective bargaining accrue to members and non-members alike, Olson (1965) argued that unions can only overcome the incentive to free-ride if membership is compulsory, or if the union can offer private incentive goods or services to its members. There is a strong association between closed shop arrangements and high union membership density. For instance, in 1984, workplace-level union density in British establishments where unions were recognised for pay bargaining was

\footnotetext{
${ }^{1}$ This legislation is akin to the agency fee arrangements in place in the US in states other than the right-to-work states, though in some circumstances non-members may still opt out even after the arrangements have been negotiated. See footnote 2 for the US.
} 
87 percent in those with a closed shop agreement, 79 percent where management strongly recommended union membership but there was no closed shop agreement, and 55 percent where there was no closed shop or strong management support (Millward, Bryson, and Forth 2000:149). Similarly, in the United States analyses of the Current Population Surveys reveal a free-rider rate in the private sector of 15 percent in states with right-to-work laws compared with 7.5 percent in states without right-to-work laws, figures that have remained fairly constant since the mid-1970s (Farber and Western 2001). ${ }^{2}$ The rise in free-riding in Britain and New Zealand since the end of the closed shop suggests that the legislation may have kept membership above the equilibrium rate that obtains where supply meets demand. ${ }^{3}$

Unions continue to generate public goods. Towards the end of the 1990s, non-members in union covered British workplaces benefited substantially from positive 'spillover' effects in terms of a wage premium and non-wage fringe benefits, creating incentives to free-ride (Forth and Millward 2002). In the new open-shop environment, where workers can choose whether or not to purchase membership on the basis of the net benefits accruing to them from doing so, the onus is on unions to 'privatize' the flow of amenities associated with membership. Private excludable goods have always been part of what unions had to offer. They include job security (Moreton 1998, 1999), professional indemnity insurance, access to union advice and representation in grievance and disciplinary matters, and influence over staffing arrangements and physical conditions. There is empirical support for the notion that private excludable goods of this type are correlated with union density among manual workers in Britain (Booth and Chatterji 1995).

Olson (1965) conceived of the decision to join a trade union as a function of an individual's appraisal of the financial costs and benefits. As the percentage of fellow workers joining the union rises, the damage the individual might do to the provision of collective goods by free-riding falls, thus strengthening the incentive to free-ride. However, Booth (1985) has argued that the 'reputation' an individual derives from membership is an important aspect of the private excludable good unions have to offer. This reputation effect is the utility individuals derive from complying with the social custom of membership, a utility first identified by Akerlof (1980:749) when he defined social custom as 'an act whose utility to the agent performing it in some way depends on the beliefs or actions of other members of the community'. Under the social custom model, peer choices help determine the reputational cost or benefit from joining, so that joining decisions are interdependent. Contrary to Olson's (1965) prediction, workers may be more prepared to join if others join since reputational benefits rise where the social custom is strong. ${ }^{4}$ The closed shop may have helped create the social custom of membership by setting membership as the 'default'. Its removal altered the 'default' position facing new workers entering an establishment such that, for the first time, whether to join became a decision based on the net benefits of membership. New entrants with marginal or no perceived benefits, by choosing not to join, began to shift the social

\footnotetext{
${ }^{2}$ Right-to-work laws make mandatory union membership or dues collection illegal. In other states, workers in covered establishments must join the union or pay agency fees. Despite the density differential across right-towork and non-right-to-work states, some analyses indicate that the laws have little independent impact on density (Hirsch and Addison 1986). The differential may be driven, in part, by differences between right-towork and non-right-to-work states in orientations towards unionization that are not directly attributable to these differences in law.

${ }^{3}$ An alternative interpretation is that desire for union membership among workers in unionized workplaces has fallen in any event. The lack of data on the desire for unionization among non-members over time means we cannot test this proposition in the UK or New Zealand.

${ }^{4}$ In extensions of this model Naylor and Cripps (1993) show that, with heterogeneous worker tastes for reputation, stable union density between zero and 100 is a possible equilibrium outcome, with the equilibrium level determined, inter alia, by union membership costs, sensitivities to social custom and levels of strike pay. Naylor and Raaum (1993) also account for the role played by management opposition to unionization.
} 
custom underpinning the reputation effects of joining. Over time, with declining membership, the reputational benefit (cost) of (not) joining the union has declined. Some social custom models of union joining posit a critical mass of membership, below which unionization is not viable. Under these conditions, reductions in membership caused by an exogenous shock, such as the removal of closed shop arrangements, may be persistent.

Changes in union density also influence unions' ability to generate collective goods through their bargaining power. ${ }^{5}$ Falling union density increases the price elasticity of union labour, other things equal, undermining union bargaining power. Consequently, although the marginal worker's decision not to join the union may not directly affect union bargaining power, the interdependence of such decisions at workplace-level can result in declining union bargaining power over time, thus reducing the perceived benefits of union membership which, itself, reinforces decisions not to join.

In addition to this economics literature, there is a literature drawing on social psychology and industrial relations that stresses three sorts of motive for union joining, namely problems at work that 'trigger' joining, such as job dissatisfaction or dissatisfaction with management; a belief that a union can be instrumental in tackling the problem; and political and ideological commitment predisposing an individual to solidaristic action to tackle perceived injustices. ${ }^{6}$ Dissatisfaction is not a sufficient condition for participation in a union (Klandermans 1986) because unions need to be seen as instrumental in alleviating dissatisfaction in order to join (Kochan 1979). Even if unions do offer a means of addressing workplace problems, the presence of employer-generated substitutes, such as non-union voice mechanisms, may dissuade workers from paying for the additional support offered by a union. Fiorito (2001) and Bryson and Freeman (2005) find such policies do reduce the desire for unionization among non-union workers in the US, but these effects are absent in Britain (Bryson and Freeman, op. cit.). ${ }^{7}$

This discussion suggests that free-riders differ from union members in a number of ways because the returns to membership are heterogeneous across workers. Free-riders:

1. Are less likely to value the collective goods unions offer. For example, highly educated workers may be able to secure good terms and conditions due to their own high individual bargaining power. Younger workers with higher mobility may place a lower value than other workers on collective grievance representation.

2. Are more likely to view unions as ineffectual.

3. Face higher fixed costs of joining relative to their income or earnings.

4. Face a low reputational cost from failing to join because union joining is not the default for their occupation or job class, or because they are located in workplaces with low or falling union density.

5. Are less likely to benefit from private union excludable goods. This may include lowtenured workers who have invested less in their current jobs than high-tenured workers.

\footnotetext{
${ }^{5}$ Hirsch and Schumacher (2001) and Stewart (1987) present empirical support for the link between higher union density and a higher union wage premium for the US and Britain respectively.

${ }^{6}$ For an exposition of the theory see Klandermans (1986). For reviews of the literature see Wheeler, Hoyt, and McClendon (1991) and McClendon, Wheeler, and Weikle (1998). For analyses testing hypotheses arising from this approach see Charlwood (2002, 2003) and Kelly (2005) for Britain and Macky, Boxall, and Haynes (2005) for New Zealand. Some, though by no means all, of the insights from this literature can be incorporated into the cost-benefit framework. For instance, one of the benefits from membership may be the psychological 'pay-off' of investing in solidaristic actions. See Schnabel (2003) for a discussion.

${ }^{7}$ Belfield and Heywood (2004) also tackle this issue with British data, but their investigation relates only to the desire for union representation on pay and combines non-members in the union and non-union sectors. Among this population, HRM practices identified by managerial respondents were generally not significantly associated with desire for union representation over pay.
} 
6. Have little attachment to the solidaristic ideological principles underpinning unionism, perhaps exhibiting greater individualism and greater sensitivity towards employer opposition to unionization.

7. Attach high value to union substitutes such as employer open-door policies.

8. Have fewer needs, problems or dissatisfactions at work that might trigger joining.

We return to these propositions in our empirical analysis. However, we do not formally test each proposition in search of causal linkages because our cross-sectional data do not permit this without making arbitrary assumptions about the direction of causation. Rather, we comment on independent correlations in the data.

\section{Data}

The analysis for Britain uses the British Worker Representation and Participation Survey 2001 (BWRPS). The analysis for New Zealand uses its counterpart, the New Zealand Worker Representation and Participation Survey 2003 (NZWRPS). Details of key data items and their values are appended (Appendix Table A1).

The BWRPS was conducted as part of the monthly BMRB Access Omnibus survey in June and July 2001. Interviews were conducted using face-to-face computer assisted personal interviewing (CAPI) techniques. Of the 3,614 people interviewed, 1,355 were eligible to take part in the survey. Our analysis is confined to the 663 respondents who reported the presence of a union, or similar body such as a staff association, that people doing their sort of job can join. The weighting schema ensures that demographic profiles match those for all employees in Great Britain aged 15 or over.

For NZWRPS, one thousand New Zealand workers, drawn randomly from residential telephone directories, were interviewed using computer assisted telephone interviewing (CATI) in January and February 2003. The sample was limited to New Zealand residents in paid employment of more than 10 hours per week and who had left secondary (high) school. Quotas for geographical regions reflected the spatial distribution of the population across the country as reported in the Household Labour Force Survey conducted by Statistics New Zealand. Although the sample was broadly representative, the data were weighted by occupation and industry to more closely fit the demographic characteristics of the total workforce. It is not possible to establish the eligibility of households who refused to answer the survey but the response rate is estimated as at least 48 percent (see Haynes, Boxall, and Macky 2003 for details of the survey). Our analysis is confined to the 451 respondents in workplaces with a union they could join.

\section{Empirical Approach}

These data allow a more precise identification of free-riders than is normally the case because they identify non-members who are eligible to join a trade union at their workplace, whereas most data sets simply identify the presence of a union or unions which the non-member may or may not be eligible to join. ${ }^{8}$ They also include detailed follow-up questions regarding

\footnotetext{
${ }^{8}$ The question BWRPS asks: 'Is there a union, or similar body such as a staff association, that represents employees to managers at your workplace and that people doing your sort of job can join?' The NZWRPS asks, 'Is there a union of any kind at your workplace?' and, if there is, 'Is it a union that people doing your sort of job can join?'
} 
individuals' decisions not to join a union, permitting a better understanding of why employees choose to free-ride.

In the next section we identify the incidence of free-riding in both countries and present descriptive information on the reasons given for choosing not to join the union. We use multivariate analyses to isolate independent associations between a range of variables and free-riding by estimating probit models for the probability of free-riding as a $(0,1)$ outcome for those eligible to join a workplace union. Analyses for both countries are weighted to allow the results to be generalized to the population from which the sample is drawn. ${ }^{9}$ The main text presents marginal effects calculated at mean values for the estimation sample. Full models with probit coefficients are appended.

Models are specified so as to be as comparable as possible across the two countries, both in terms of the set of covariates used and their precise specification. Controls include demographics (gender, age, ethnicity, education), job (hours, tenure with the employer, whether the job is considered 'part of your long-term career', managerial and supervisory status) and workplace characteristics (organisational size and public sector). ${ }^{10}$ There remain some differences in the specifications, most notably the use of banded gross pay in BWRPS, whereas NZWRPS contains banded personal pre-tax income. All control variables are described and mean values listed in the Data Appendix.

Some of these variables are of interest in their own right given the theory outlined earlier. In particular we might expect the following relationships:

1. Lower probabilities of free-riding with high tenure and among older workers. These workers are more likely to have entered the workplace at a time when closed shop provisions were still in place and the social custom of membership better established. Furthermore, they are likely to have poorer outside job options, which would increase the value they attach to private excludable goods such as individual grievance representation.

2. Higher probabilities of free-riding among those with low wages, low hours and those who perceive their jobs as 'non-career' jobs, since the fixed costs of joining are relatively high for these workers.

3. Higher probabilities of free-riding for the very well paid and highly qualified due to their relatively high bargaining power and better outside labour market opportunities.

4. Higher probabilities of free-riding among occupations where union joining is not the custom, notably management, where the reputational cost of not joining is likely to be low.

5. Lower probabilities of free-riding in public sector industries where the social custom of membership is strong and the gross benefits from membership are likely to be high, as in public administration and health.

6. Higher probabilities of free-riding in larger organizations where the marginal effect of not joining on the provision of collective goods will be lowest.

For some variables the theoretical propositions cut in different directions. For instance, point 2 above suggests higher probabilities of free-riding among those with low wages whereas point 3 suggests higher probabilities of free-riding among the higher-paid. Also, variables such as age and tenure are correlated. Thus the independent association between

\footnotetext{
${ }^{9}$ Multivariate analyses run on unweighted data produce similar results to those reported here and are available from the author on request.

${ }^{10}$ If analyzed separately, richer models can be specified. For instance, the BWRPS contains a richer set of covariates including marital and parental status, region, local area characteristics, and workplace size. These fuller model specifications do not alter the main findings presented in the paper. These alternative specifications are available from the author on request.
} 
each variable and free-riding is an empirical matter that can only be adequately explored with multivariate analyses.

In addition to these 'baseline' characteristics we create measures capturing features of the individual, the workplace and the union that the literature review indicates are likely to affect the propensity to free-ride. These measures are described in detail in the Data Appendix. Although some derivations differ across the two surveys due to differences in survey design and institutional settings, the model specifications remain broadly comparable across the two countries.

First, we identify the number of workplace needs that employees express. Both surveys asked workers about their satisfaction with the influence they had over workplace decisions, perceptions of management's ability to deal with workplace issues, the presence of particular problems at work, and general workplace climate. Using identical or near-identical measures in both surveys, we coded responses to questions in these areas as $0 / 1$ variables, where 0 means no problem/need and 1 means a problem/need. We then summed these measures to obtain the total number of needs, with scores running from zero (no needs) to a maximum of 13. This approach makes it relatively easy to compare the reported needs across the surveys. These needs may 'trigger' desire for unionization and so should be correlated with a greater desire for unionization among non-union workers. New Zealand's employees had fewer needs than Britain's: 43 percent of New Zealanders in unionized workplaces had no needs, compared to 36 percent of British workers in unionized workplaces. The mean scores were 2.1 and 2.4 respectively. However, non-members' needs were similar across the two countries: non-members in both countries had a mean of 1.9 needs. Thus the needs 'trigger' for non-members to join their workplace union appears similar across the two countries.

The second set of measures relate to union instrumentality. Where unions are perceived as instrumental in effecting change, this should reduce employees' propensity to free-ride. Identical additive scales running from zero to six were constructed for both countries, with a union scoring ' 1 ' on the effectiveness scale each time it was perceived as 'excellent' or 'good' on six performance indicators. New Zealand's employees were more likely than British employees to view the workplace union as effective, the mean scores being 3.4 and 2.8 respectively. However, the difference was largely accounted for by members' perceptions (mean scores of 4.1 and 3.1) rather than non-members' (for whom the mean scores were 2.7 and 2.4 respectively).

The second union instrumentality measure is a dummy variable identifying workers who think things would be worse 'if there was no union' (at 'your workplace' in BWRPS and 'personally' in NZWRPS). In both countries, 54 percent of employees gave this response. Once again, members in New Zealand seemed more certain of the benefits of unionization than members in Britain: 75 percent thought things would get worse in the absence of a union, compared to 66 percent of British members. Non-members gave similar responses across countries with 28 percent of New Zealand's non-members saying things would get worse compared to 31 percent in Britain.

On both union effectiveness measures New Zealand's unions were perceived as more effective than Britain's unions among their members, whereas non-members' perceptions of union effectiveness did not differ very much across the two countries. The membership differential may indicate that New Zealand's unions are relatively better at privatizing the returns to membership than their British counterparts. The privatization of these returns might explain why non-members do not observe union effectiveness to the same degree. Alternatively, non-members may recognize the private benefits of membership to current members but, for whatever reasons, do not think these benefits would accrue to them if they joined. 
Third, our data contain potential union substitutes. Three of these - a joint consultative committee (JCC), a managerial 'open door' policy, and an HR department - are common to both surveys and so we concentrate on these in our main analyses. In our sample of employees in unionized workplaces, British workers were more likely than New Zealanders to be employed in a workplace with a JCC, whereas New Zealanders were more likely to identify an 'open door' policy and HR departments.

In addition, BWRPS identifies the presence of formal grievance procedures and five types of performance-related payment. NZWRPS includes employee involvement programs, regular meetings between management and employees, and committees of employees. All of these have the potential to meet employee problems and needs, and thus reduce the desire for employees to join the union, so we shall also comment on their effects.

Fourth, we include employee perceptions of managerial attitudes towards unionization since these can influence employees' views as to the personal cost of joining the union and the prospects for a union making headway with an employer. Employees perceive greater managerial opposition to unions in New Zealand than they do in Britain, a perception that is shared by members and non-members alike. Ten percent of British employees in unionized workplaces thought managers were 'opposed' to unions, the figure being similar among members and non-members. In New Zealand, perceived management opposition to unions was more than twice as common, with 24 percent viewing managers as 'opposed' to unions. Furthermore, unlike Britain, non-members in New Zealand were more likely than members to view managers as opposed to unions ( 27 percent did so, compared to 21 percent of members). New Zealanders were also less likely than British workers to perceive management as being 'in favour' of unions - 31 percent against 41 percent in Britain - a differential apparent among members and non-members, with New Zealand's non-members least likely of all to view employers as favourable.

The fifth set of measures captures individuals' ideological orientation. These measures differ across the two surveys. BWRPS contains two measures of employees' perceptions of unions in general. Conditioning on perceptions of union effectiveness at the workplace, positive perceptions of unions in general are considered an indicator of a general positive orientation towards unions and should increase the perceived net benefits of membership. Half (51 percent) of British employees in unionized workplaces strongly agreed that strong unions were needed to protect employees' conditions and wages, the agreement rate being almost twice as high among members as among non-members (61 percent against 35 percent). On the second measure, only around one-third (36 percent) of British employees in unionized workplaces strongly disagreed with the statement 'trades unions are old fashioned/have no future in modern Britain', the rate of disagreement being twice as high among members as non-members (44 percent compared to 22 percent). The NZWRPS measure of ideology is based on factor analysis of five political attitude statements which have been validated in other surveys. They are used to construct a "left-right" index which positions individuals on a political spectrum from left to right. The expectation is that those of a more leftward persuasion are more likely to support unions. Members were more to the "left" of the scale than non-members, as one might have anticipated. ${ }^{11}$

Finally, NZWRPS asks: 'About what proportion of employees in your workplace are in your union?' with responses coded from 'almost none' through to 'almost all/all'. Workplace-level union density can be a proxy for the social norm of union joining, and so may measure the reputational benefit of joining, a benefit which should rise with the percentage organized. On the other hand, from Olson's perspective, the potential impact of

\footnotetext{
${ }^{11}$ Other studies have identified an independent association between being on the left of this scale and union membership (Bryson and Gomez 2003).
} 
not joining on public goods provision falls with rising membership, lowering the probability of joining. Which factor dominates is an empirical question. BWRPS does not contain a density measure.

The modelling approach is to construct a 'baseline' model, then add and remove each block of additional variables described to test their effects conditional upon 'baseline' characteristics. In the final models all variables are entered together. Models are run on data pooled from both countries, with a New Zealand dummy identifying country effects over and above those accounted for in the model. Separate country models are also presented to establish how effects vary across the two countries. These analyses are run on 1,088 cases (646 for Britain and 442 for New Zealand), having dropped a small number of cases with missing data on education, hours or tenure and, for a small number of New Zealand cases, a missing weighting variable.

\section{The Incidence of Free-Riding}

Forty-five percent of New Zealanders employed in unionized workplaces are free-riders, that is, they are non-members working in a workplace with a union that they could join. This freeriding rate in NZWRPS is 10 percentage points above the 35 percent among British employees in unionized workplaces. This differential is apparent across most types of employee, the exceptions being women, managers, non-supervisors, those with low tenure, and the small percentage of employees scoring highly on the union effectiveness scale (Table 2).

The gender difference in free-riding across the two countries is particularly striking. In Britain, the incidence of free-riding is 13 percentage points higher among women than it is among men. In New Zealand, it is the other way round, the free-riding rate being 13 percentage points higher for men than for women.

The other striking difference relates to free-riding among managers and supervisors. In Britain, free-riding is more common among managers than among non-managers but is less common among supervisors than among those without supervisory responsibilities. In New Zealand, on the other hand, although the percentage point differences are smaller than for Britain, free-riding is more prevalent among non-managers than among managers, and among supervisors compared with non-supervisory workers. These differences may be accounted for by differences in survey questions across the two countries, as explained in the Data Appendix.

In both countries, free-riding is most prevalent among younger workers but remains roughly constant once workers reach their mid-30s. It is lower among the more highly qualified, though the effects are not pronounced. Free-riding declines markedly with hours worked, with gross pay/income, with tenure and among those who perceive their jobs as 'career' jobs. It is lower in the public sector and among those employed by larger organizations.

In both countries, free-riding becomes less common among those employees with three or more needs, whereas there is little difference in free-riding between those with no needs and those with one or two needs. The rate of free-riding is associated with perceptions of union effectiveness, as noted earlier: it is much lower among those who think things would get worse without the union and drops with higher union effectiveness scores except among the small percentage scoring close to the top of the effectiveness scale. Perceptions of management attitudes towards unions are also associated with free-riding. The rate of freeriding is lowest among those who think management 'favours' unions, but there is no difference in either country in the free-riding rates of those perceiving management to be 
opposed and those who see management as 'neutral'. The highest free-riding rates are among those who say they do not know management's attitudes to unions or refuse to answer the question.

Managerial policies and practices that might substitute for unions do not seem to be associated with free-riding: the free-riding rates in the presence of HR departments, open door policies and JCCs are close to the country averages. The exception is performancerelated payments: half of British employees in unionized workplaces using them are freeriders.

As anticipated, ideological support for the role of unions in general is associated with a lower incidence of free-riding, as is being on the "left" of the "left-right" scale in New Zealand.

Finally, the percentage of New Zealand's employees who say they are a non-member falls monotonically with what they believe is the rough proportion of employees who are union members at their workplace. Of course, there is a mechanistic relationship here: by definition, an employee is much less likely to be a non-member where all or nearly all the employees in the workplace are members. However, workplace density may also be correlated with the economic or reputational benefits of membership.

\section{Reasons Employees Give for Free-Riding}

Before moving on to establish which factors are independently associated with free-riding in multivariate analyses, we consider why workers choose not to join a union when there is a union available to them at their workplace. When interpreting responses it is worth bearing in mind that many non-members had never been confronted with the question by union organizers. Fifty-five percent of BWRPS non-members eligible to join a union at their workplace said they had never been asked to join the union. ${ }^{12}$ This is a serious organizing failure on the part of trade unions, since 36 percent said they would be 'very' or 'quite' likely to join if asked.

BWRPS asks non-members how important four factors were in their 'decision' not to join the union at their workplace, using a four-point scale from 'very important' to 'not at all important'. The chief reason given, mentioned as 'very' or 'quite' important by four-in-ten non-members, was that the 'union does not achieve anything I value', indicating the importance of perceived union instrumentality (Table 3, Panel A). The second most important reason, identified as such by one-third of non-members, was 'I get all the benefits anyway', a conscious recognition that they are free-riding on collective goods generated by the union. ${ }^{13}$ One might have expected a negative correlation between these two factors in determining the decision not to join the union since the first statement implies that there are few, if any, benefits one might derive from membership. In fact, they are positively and significantly correlated (Table 3, Panel B). The price of joining was cited as important by 30 percent of non-members. A similar proportion cited 'people doing my job just don't join', a clear indication of the importance of social customs and norms in the joining decision.

One potential criticism of this approach is that there may be many reasons for not joining other than those offered in the questionnaire. In the event, over two-thirds of British nonmembers (69 percent) cited at least one of the reasons as either 'quite important' or 'very important'. However, 10 percent of non-members said all four reasons were 'not at all

\footnotetext{
${ }^{12}$ In NZWRPS, the question was only asked of non-members eligible to join a union at their workplace who had never belonged to a union $(\mathrm{N}=63)$. Of these, 34 percent report that they had never been asked to join the union.

${ }^{13}$ Haynes and Boxall (2005) refer to these as "calculating" free-riders.
} 
important' so that, for a small minority, the question is not getting at their reasons for not joining.

The NZWRPS information on reasons for not joining is different for two reasons. First, the question asks non-members to indicate how strongly they agreed or disagreed with six statements given as 'reasons why some people don't belong to unions'. Second, the question was filtered such that it was only asked of employees who had never been union members ('never-members', thus excluding those who had been members of a union at some time in the past). This severely restricted the numbers answering the question (unweighted $\mathrm{N}=65$ ) and means the results cannot be extrapolated to all non-members in unionized workplaces. The responses are nevertheless informative and can be taken as indicative of the rank order of responses that non-members as a whole might give. The primary reason identified for not joining was that 'I get all the benefits anyway', a statement to which two-thirds (64 percent) of never-members agreed or strongly agreed. Next came 'The union does not achieve anything I value' and 'People doing my job don't join trade unions', statements to which around two-fifths (44 and 43 percent respectively) of never-members agreed. A little over one-third (37 percent) agreed with the statements that 'Membership fees are too high/too expensive' and 'Unions do not cooperate enough for the good of the workplace'. Last came the statement 'I don't believe in unions', cited by 28 percent of never-members.

Although the sample base and rating scales for the British and New Zealand questions are not comparable, these findings indicate that non-members tend to have multiple reasons for not joining a union, with 'calculating' free-riding, social norms, union instrumentality, the financial costs of joining and ideological motivations all playing a role.

\section{Factors Associated with Free-Riding}

We identify independent factors associated with free-riding using probit analyses as described earlier. The full models with probit coefficients are presented in the Data Appendix. Tables 1-5 in the text report changes in the estimated probability of being a freerider relating to various employee, job and workplace characteristics, arising from change in each independent, continuous variable and of switches in the value of discrete variables. The marginal effects are evaluated at the mean characteristics of the estimation sample.

Model (1) in Table 4, presented in full together with the other models in Appendix Table A2, contains all 'baseline' characteristics for employees in Britain and New Zealand. The adjusted Wald test indicates the variables are jointly significant $(f(23,1065)=6.13$, $\mathrm{p}>\mathrm{f}=.0000$ ). The increase in free-riding probabilities with shorter hours and low pay may be associated with the fixed pecuniary and effort costs attached to joining. The increased propensity for free-riding among managers relative to other employees is consistent with low reputational costs attached to not joining among those in managerial grades. As anticipated, older workers and those with long tenure have lower probabilities of free-riding, perhaps because they have fewer outside job opportunities than lower tenure and younger workers and, as such, are more likely to benefit from the private excludable goods available through the union, such as representation in grievance matters. It is also possible that, conditioning on tenure, age is capturing a cohort effect, with some of these older workers joining unions at a time when the closed shop was in force. The lower probability of free-riding in the public sector is consistent with the social custom of joining in the sector and with potentially higher returns to union membership in higher density sectors. Similar interpretations might apply to the lower probability of free-riding in larger organisations since these are known to have higher union density. There is no support for Olson's contention that free-riding will be more 
prevalent in larger organizations since the marginal effect of free-riding on the production of collective goods will be less apparent.

Controlling for the 'baseline' characteristics, higher needs are associated with a lower probability of free-riding (Model (2)). So too is perceived union instrumentality (Model (3)). The marginal effect of believing that things would be worse in the absence of the union is particularly large, reducing the probability of free-riding by 31 percent for individuals with mean characteristics for the sample. Perceptions of managerial support for unions are also associated with a lower probability of free-riding (Model (4)). However, HR practices were not significant when added to the baseline model, indicating that they were neither a substitute for nor complementary to unionization.

In Model (5) all these variables are entered together. Little changes, although tenure with the employer loses its significance and employer neutrality becomes negative and significant at a 90 per cent confidence level.

Within this pooled sample, the free-riding rate is 38 percent, with the rate around 10 percentage points higher for New Zealanders than British employees. Thus, when added to a constant, the New Zealand dummy has a marginal effect of 0.10. In Model (1) this has risen to 0.15 indicating that compositional differences between employees in the two countries obscures what is an even higher underlying free-riding probability in New Zealand. The size of this effect does not change when the needs scale is added. However, the marginal effect of the New Zealand dummy increases to 0.21 when union effectiveness is controlled for, reflecting the fact that unions are perceived as more effective in New Zealand than they are in Britain. Controlling for this, the propensity to free-ride grows in New Zealand relative to Britain. In Model (4), when perceptions of management attitudes to unions are added to the baseline model, the marginal effect of New Zealand falls a little compared with Model (1). This is because managerial opposition to unions, which is more widespread in New Zealand than in Britain, accounts for some of the free-rider gap so that, when it is accounted for, the gap narrows a little. In the full model the marginal effect of New Zealand is 0.17 , indicating a sizeable difference in free-rider propensities that is not accounted for by other factors in the model.

Table 5 presents identically specified separate models for New Zealand and Britain so that coefficients are no longer constrained to be equivalent across the two countries. (The full models are presented in Appendix Table A3). For ease of presentation the marginal effects are only presented for the baseline and full models in Table 5.

Permitting coefficients to differ across countries allows the contrasting effects of gender, apparent in the descriptive analyses, to come through. The positive association between being male and free-riding in New Zealand is large and becomes even stronger in the full model (Model (3)). The independent effect of gender is weaker in Britain and the negative effect of being male, apparent in the baseline model, becomes non-significant in the full model. The positive relationship between youth and free-riding is apparent for both countries, but it is stronger in New Zealand than in Britain. Independent associations with ethnicity, qualifications, pay, and career jobs are weak and not robust to model specification. Hours effects are common across both countries, whereas negative associations with long tenure and large organizations are confined to Britain. The probability of free-riding is higher among managers than among non-managerial employees in both New Zealand and Britain, something that is not apparent in the descriptive analyses, the marginal effect being similar in both countries.

In both countries, higher needs and perceptions of more effective unions are independently associated with lower probabilities of free-riding, while substitutes are not significant. Whereas managerial opposition to unions was more widespread in New Zealand than Britain, it is only independently associated with free-riding in Britain. 
We ran further models to establish the independent effect of variables that were only available for one country or the other. These models (available from the author on request) examined the role played by ideological convictions, a wider list of substitutes for trade unions, and the effect of union density within the workplace. As expected, a general belief that strong unions are needed to protect working conditions and wages, and the belief that unions are not old fashioned but have a future in Britain are both negatively associated with free-riding. The 'left-right' scale, on the other hand, is not significantly associated with freeriding in New Zealand, whether entered as a linear term, a linear term with a quadratic term, or as quartiles of the distribution. Turning to potential substitutes for unionization, the only practice that is significant in Britain is the positive effect of performance-related pay. For New Zealand, the only significant association is a negative one between free-riding and regular meetings between management and employees. Finally, as anticipated, higher workplace union density has a strong independent effect in reducing the probability of freeriding in New Zealand.

\section{Discussion and Conclusions}

Free-riders are an increasing problem for trades unions in Britain and New Zealand following legislation in the late 1980s and early 1990s that made enforcement of a closed shop unlawful. Using unique comparable data for the two countries, we find the incidence of freeriding is 10 percentage points higher in New Zealand than it is in Britain. The regressionadjusted gap is even larger.

Non-members give a range of reasons for not joining their workplace union. These include the explicit recognition of the incentive to free-ride on the collective goods the union produces, but they also include concerns about the net benefits of joining due to union ineffectiveness, social norms in not joining, and the pecuniary cost of joining. Multivariate analyses reveal patterns of free-riding consistent with a number of theoretical propositions. Variance in the social custom of joining across sectors and occupations may explain higher probabilities of free-riding among managers and lower probabilities of free-riding in the public sector and in high density workplaces. A concern for unions is that, with the end of the closed shop and the ensuing decline in union density, it is increasingly the case that the social custom is not to join the union.

The number of problems or needs non-members have in unionized workplaces is similar in Britain and New Zealand. In both countries, the more problems workers have, the less likely they are to free-ride, the size of the effect being similar. This implies that workers are not blaming unions for the parlous state of their workplace but, instead, may see unions as part of the solution. Consistent with this, perceptions of union instrumentality are associated with lower probabilities of free-riding. This is good news for unions since it implies that, at least to some degree, converting non-members located in unionized workplaces is something within their control. However, a high percentage of workers in both countries do not view unions as effective in delivering better outcomes for workers. On average, employees in New Zealand viewed unions as more effective than their British counterparts. However, the difference was accounted for by the perceptions of existing members: perceptions of non-members were similar. The implication is that unions in both countries could do much more to improve worker perceptions that they can help 'fix' problems at work.

Perhaps some time ago, unions may have hoped that employees' ideological attachment to trades unionism would be sufficient to guarantee loyalty to the union. This may no longer be the case, but ideological attachment remains a significant factor reducing the propensity to free-ride in Britain. The evidence for New Zealand is less clear-cut. 
In the US, it is often argued that intractable employer opposition to unionization prevents unions from gaining a foothold, resulting in frustrated demand for unionization (Bryson and Freeman 2005). In this paper, we find evidence that employers can also have an important role to play in employees' decisions to join a union even when the union already has a foothold. Although employees perceive management to be less tolerant of unions in New Zealand than they do in Britain, the independent association between free-riding and management opposition to unions is only significant for Britain. It may well be the case that there is some misalignment between employee perceptions of employer attitudes towards unionization and employers' professed attitudes. Nevertheless, what matters in terms of employees' decisions about union joining is their own perception of management attitudes, as we find here.

In both countries, evidence that HR policies and practices can substitute for unions is scant. In Britain, the only practice associated with an increased propensity to free-ride was performance-related pay whereas, in New Zealand, the only practice significantly associated with free-riding was regular meetings between management and employees, the effect being to reduce the probability of free-riding.

Whereas the New Zealand government has recognized the free-rider problem facing unions by introducing legislation in support of agency shops, this is not an area that the British government plans to legislate on. Indeed, it recently stated:

"The Government believes every employee should be free to decide to join a trade union. But equally every employee should be free not to join. Trade unions should be voluntary organisations. The abolition of the closed shop was one of the many employment law reforms of the 1980s that were justified and will remain. There will be no return to the closed shop." (http://www.dti.gov.uk/er/fairness/part4.htm)

It is against this background that trade unions in Britain have just begun to secure agency shop agreements through workplace votes. One of the first such agreements was secured by the Transport and General Workers Union in June 2005. According to Tony Woodley, General Secretary of the TGWU:

"The deal with East Thames Buses, accepted by a ballot of the entire workforce, should prove to be a model for workplaces all over the country. Already, several non-members realise what the union does for them and are now joining."

(http://www.tgwu.org.uk/Templates/Journal.asp?NodeID=91782\&int1 stParentNodeID=4246 $\underline{9 \text { \&int } 2 \text { ndParentNodeID }=89440)}$

Whether New Zealand's new legislative framework and Britain's voluntary agreements can increase the percentage of workers paying union dues, or re-weight the cost/benefit calculus in favour of union joining remains to be seen. 


\section{References}

Akerlof, George A. 1980. "A Theory of Social Custom, of Which Unemployment May be One Consequence.” Quarterly Journal of Economics 94(4):749-75.

Belfield, Clive R., and John S. Heywood. 2004. "Do HRM Practices Influence the Desire for Unionization? Evidence across Workers, Workplaces, and Co-Workers for Great Britain." Journal of Labor Research 25(2):279-99.

Booth, Alison L. 1995. The Economics of the Trade Union. Cambridge: Cambridge University Press.

Booth, Alison L. 1985. "The Free Rider Problem and a Social Custom Model of Trade Union Membership." The Quarterly Journal of Economics 100(1):253-61.

Booth, Alison L., and Monojit Chatterji. 1995. "Union Membership and Wage Bargaining When Membership is Not Compulsory." Economic Journal 105(4):345-60.

Bryson, Alex, and Richard Freeman. 2005. "The Role of Worker Needs in Generating Desire for Voice: the Case of Workers in the US and the UK." NBER Working Paper.

Cambridge, MA: National Bureau of Economic Research.

Bryson, Alex and Rafael Gomez, 2003. "Why Have People Stopped Joining Unions?”, Centre for Economic Performance Discussion Paper No.589, London School of Economics

Charlwood, Andy. 2002. "Why Do Non-union Employees Want to Organise? Evidence from Britain." British Journal of Industrial Relations 40(3):463-91.

Charlwood, Andy. 2003. "Willingness to Unionize amongst Non-Union Workers." In Representing Workers: Union Recognition and Membership in Britain, edited by Howard Gospel and Stephen Wood, pp. 51-71. London: Routledge,

Farber, Henry S., and Bruce Western. 2001. "Accounting for the Decline of Unions in the Private Sector, 1973-1998." Journal of Labor Research 22(3):459-85.

Fiorito, Jack. 2001. "Human Resource Management Practices and Worker Desires for Union Representation." Journal of Labor Research 21(2):335-54.

Forth, John, and Neil Millward. 2002. "Union Effects on Pay Levels in Britain". Labour Economics 9(4):547-61.

Harbridge, Raymond, and David Wilkinson. 2001. "Free Riding: Trends in Collective Bargaining Coverage and Union Membership Levels in New Zealand." Labor Studies Journal 26(3):51-72.

Haynes, Peter, and Peter Boxall. 2004. "Free-Riding in New Zealand: Incidence, Motives and Policy Implications." Labour and Industry 15(3):47-63.

Haynes, Peter, Peter Boxall, and Keith Macky. 2003. New Zealanders' Influence at Work: Report on the New Zealand Worker Representation and Participation Survey. Auckland: University of Auckland Business School.

Haynes, Peter, Peter Boxall, and Keith Macky. 2006. "Union Reach, the 'Representation Gap' and the Prospects for Unionism in New Zealand." Journal of Industrial Relations 48(2) (forthcoming).

Hirsch, Barry T., and John T. Addison. 1986. The Economic Analysis of Unions. London: Allen and Unwin. 
Hirsch, Barry T., and Edward J. Schumacher. 2001. "Private Sector Union Density and the Wage Premium: Past, Present, and Future." Journal of Labor Research 22(3):487-518.

Kelly, John. 2005. "Social Movement Theory and Union Revitalization." In Trade Unions: Resurgence or Demise? edited by Sue Fernie and David Metcalf, pp. 62-82. London: Routledge

Klandermans, Bert. 1986. "Psychology and Trade Union Participation: Joining, Acting, Quitting." Journal of Occupational Psychology 59(3):189-204.

Kochan, Thomas A. 1979. "How American Workers View Labor Unions." Monthly Labor Review 102(4):23-31.

Lawler, John J. 1986. "Union Growth and Decline: The Impact of Employer and Union Tactics." Journal of Occupational Psychology 59(3):217-30.

Macky, Keith A., Peter Boxall, and Peter Haynes. 2005. "Predictors of Union Belonging and Joining Intentions in New Zealand.” University of Auckland Business School, Universdity of Auckland. Mimeo.

McClendon, John A., Hoyt N. Wheeler, and Roger D. Weikle. 1998. "The Individual Decision to Unionize." Labor Studies Journal, 23(3):34-54.

Millward, Neil, Alex Bryson, and John Forth. 2000. All Change at Work? British Employment Relations, 1980-1998, as Portrayed by the Workplace Industrial Relations Survey Series. London: Routledge.

Moreton, David R. 1998. "An Open Trade Union Model of Wages, Effort and Membership." European Journal of Political Economy 14(3):511-27.

Moreton, David R. 1999. "A Model of Labour Productivity and Union Density in British Private Sector Unionised Establishments.” Oxford Economic Papers 51(2):322-44.

Naylor, Robin A., and Martin Cripps. 1993. "An Economic Theory of the Open Shop Trade Union," European Economic Review 37(8):1599-620.

Naylor, Robin A., and Oddbjorn Raaum. 1993. "The Open Shop Union, Wages, and Management Competition." Oxford Economic Papers 45:589-604.

Olson, Mancur, Jr. 1965. The Logic of Collective Action: Public Goods and the Theory of Groups. Cambridge, MA: Harvard University Press.

Schnabel, Claus. 2003. "Determinants of Trade Union Membership". In The International Handbook of Trade Unions, edited by John T. Addison and Claus Schnabel, pp.13-43. Cheltenham: Edward Elgar.

Schumacher, Edward J. 1999. "What Explains Wage Differences between Union Members and Covered Nonmembers?" Southern Economic Journal 65(3):493-512.

Stewart, Mark. B. 1987. "Collective Bargaining Arrangements, Closed Shops and Relative Pay." Economic Journal 97(386):140-56.

Wheeler, Hoyt N., and John A. McClendon. 1991. "The Individual Decision to Unionize." In The State of the Union, edited by George Strauss, Daniel G. Gallagher and Jack Fiorito, pp. 47-83. Madison, WI: Industrial Relations Research Association.

Wood, Stephen, Sian Moore, and Keith Ewing. 2003. "The Impact of the Trade Union Recognition Procedure under the Employment Relations Act, 2000-2.” In Representing Workers: Union Recognition and Membership in Britain, edited by Howard Gospel and Stephen Wood, pp. 119-143. London: Routledge. 
Table 1: \% non-members in unionized workplaces, Britain, 1980-2001

\begin{tabular}{|c|c|c|c|c|c|c|c|c|c|}
\hline & \multicolumn{4}{|c|}{$1980 \mathrm{~s}$} & \multicolumn{5}{|c|}{$1990 \mathrm{~s}$} \\
\hline & 1980 & $1983-85$ & 1984 & 1986-89 & 1990 & 1990-94 & $1995-98$ & 1998 & 1999-01 \\
\hline WERS & 22 & - & 28 & - & 32 & - & - & 44 & - \\
\hline BSAS & - & 28 & - & 27 & - & 32 & 37 & - & 40 \\
\hline
\end{tabular}

Sources: WERS adapted from Millward et al. (2000: 142). Establishments with 25+ employees where one or more unions recognized for pay bargaining and where number of members reported. 1980 figure is full-time employees only.

BSAS adapted from Bryson and Gomez, 2005, Table 8. Employees working 10+ hours per week. 
Table 2: The incidence of free-riding among employees in unionized workplaces in Britain and New Zealand, by employee characteristics

\begin{tabular}{|c|c|c|}
\hline & Britain & New Zealand \\
\hline All & 35 & 45 \\
\hline \multicolumn{3}{|l|}{ Sex: } \\
\hline Men & 29 & 51 \\
\hline Women & 42 & 38 \\
\hline \multicolumn{3}{|l|}{ Age (years): } \\
\hline $15-24$ & 64 & 76 \\
\hline 25-34 & 39 & 56 \\
\hline $35-44$ & 28 & 39 \\
\hline $45-54$ & 27 & 40 \\
\hline $55+$ & 27 & 40 \\
\hline \multicolumn{3}{|l|}{ Ethnicity: } \\
\hline White & 35 & 45 \\
\hline Non-white & 30 & 42 \\
\hline \multicolumn{3}{|c|}{ Qualifications: } \\
\hline Low & 36 & 50 \\
\hline Middle & 37 & 42 \\
\hline High & 31 & 42 \\
\hline \multicolumn{3}{|c|}{ Hours worked: } \\
\hline$<30$ & 57 & 62 \\
\hline $30-40$ & 34 & 47 \\
\hline$>40$ & 23 & 36 \\
\hline \multicolumn{3}{|c|}{ Tenure with employer: } \\
\hline$<2$ years & 52 & 54 \\
\hline 2-4 years & 44 & 49 \\
\hline 5-9 years & 32 & 45 \\
\hline $10+$ years & 23 & 36 \\
\hline \multicolumn{3}{|l|}{ Career job: } \\
\hline Yes & 32 & 41 \\
\hline No & 43 & 53 \\
\hline \multicolumn{3}{|l|}{ Manager: } \\
\hline Yes & 46 & 42 \\
\hline No & 34 & 46 \\
\hline
\end{tabular}




\begin{tabular}{|c|c|c|}
\hline $\begin{array}{l}\text { Supervisor: } \\
\text { Yes } \\
\text { No } \\
\end{array}$ & $\begin{array}{l}29 \\
39 \\
\end{array}$ & $\begin{array}{l}47 \\
41 \\
\end{array}$ \\
\hline $\begin{array}{l}\text { Pay: } \\
\text { Low } \\
\text { Middle } \\
\text { High } \\
\text { DK/refused }\end{array}$ & $\begin{array}{l}56 \\
30 \\
23 \\
40\end{array}$ & $\begin{array}{l}65 \\
44 \\
39 \\
72\end{array}$ \\
\hline $\begin{array}{l}\text { Sector: } \\
\text { Public } \\
\text { Private }\end{array}$ & $\begin{array}{l}28 \\
41 \\
\end{array}$ & $\begin{array}{l}34 \\
52\end{array}$ \\
\hline $\begin{array}{l}\text { Organizational size: } \\
<=1,000 \text { employees } \\
>1,000 \text { employees } \\
\text { DK size }\end{array}$ & $\begin{array}{l}48 \\
30 \\
30\end{array}$ & $\begin{array}{l}53 \\
40 \\
33\end{array}$ \\
\hline $\begin{array}{l}\text { Needs: } \\
0 \\
1 \text { or } 2 \\
3+ \\
\end{array}$ & $\begin{array}{l}38 \\
40 \\
27 \\
\end{array}$ & $\begin{array}{l}46 \\
49 \\
38 \\
\end{array}$ \\
\hline $\begin{array}{l}\text { Workplace worse without union: } \\
\text { Yes } \\
\text { No/DK }\end{array}$ & $\begin{array}{l}20 \\
52 \\
\end{array}$ & $\begin{array}{l}23 \\
70 \\
\end{array}$ \\
\hline $\begin{array}{l}\text { Union effectiveness score: } \\
0 \\
1 \\
2 \\
3 \\
4 \\
5 \\
6 \\
\end{array}$ & $\begin{array}{l}53 \\
38 \\
33 \\
28 \\
18 \\
32 \\
33\end{array}$ & $\begin{array}{l}76 \\
65 \\
61 \\
41 \\
28 \\
30 \\
34 \\
\end{array}$ \\
\hline $\begin{array}{l}\text { Management attitudes: } \\
\text { Favours union } \\
\text { Neutral } \\
\text { Opposes union } \\
\text { Don't know }\end{array}$ & $\begin{array}{l}25 \\
40 \\
40 \\
58\end{array}$ & $\begin{array}{l}32 \\
48 \\
51 \\
54\end{array}$ \\
\hline
\end{tabular}




\begin{tabular}{|c|c|c|}
\hline $\begin{array}{l}\text { Substitutes: } \\
\text { HR department } \\
\text { Open door } \\
\text { JCC }\end{array}$ & $\begin{array}{l}32 \\
37 \\
33\end{array}$ & $\begin{array}{l}41 \\
44 \\
43\end{array}$ \\
\hline \multicolumn{3}{|c|}{ Variables only available in one of the countries: } \\
\hline $\begin{array}{l}\text { Union substitutes: } \\
\text { Grievance procedure } \\
\text { Profit-related pay } \\
\text { ESOP } \\
\text { SAYE } \\
\text { Performance-related pay } \\
\text { Cash bonuses } \\
\text { DK about performance pay } \\
\text { Regular meetings with management } \\
\text { Employee committee } \\
\text { EI program }\end{array}$ & $\begin{array}{l}28 \\
41 \\
35 \\
32 \\
49 \\
30 \\
66 \\
\text { NA } \\
\text { NA } \\
\text { NA }\end{array}$ & $\begin{array}{l}\text { NA } \\
\text { NA } \\
\text { NA } \\
\text { NA } \\
\text { NA } \\
\text { NA } \\
\text { NA } \\
38 \\
42 \\
39\end{array}$ \\
\hline $\begin{array}{l}\text { Trade union modern } \\
\text { Yes } \\
\text { No }\end{array}$ & $\begin{array}{l}20 \\
43 \\
\end{array}$ & NA \\
\hline $\begin{array}{l}\text { Need strong union: } \\
\text { Yes } \\
\text { No }\end{array}$ & $\begin{array}{l}23 \\
47 \\
\end{array}$ & NA \\
\hline $\begin{array}{l}\text { Left-right scale quartiles: } \\
\text { Bottom quartile } \\
\text { Second quartile } \\
\text { Third quartile } \\
\text { Top quartile }\end{array}$ & NA & $\begin{array}{l}39 \\
42 \\
46 \\
53\end{array}$ \\
\hline $\begin{array}{l}\text { Union density at the workplace: } \\
\text { Almost all/all } \\
\text { A clear majority } \\
\text { About half } \\
\text { A small minority } \\
\text { Almost none } \\
\text { Don't know }\end{array}$ & NA & $\begin{array}{l}12 \\
32 \\
56 \\
72 \\
88 \\
78\end{array}$ \\
\hline
\end{tabular}

Notes: (1) Unweighted $\mathrm{N}=1,088,646$ British, 442 New Zealanders (2) Figures are weighted with survey weights. (3) Details of data derivation are given in the Data Appendix. 
Table 3: Factors influencing British employees' decisions not to join a union they were eligible to join

\section{Panel A: Row Percentages}

\begin{tabular}{|l|l|l|l|l|l|}
\hline & $\begin{array}{l}\text { Very } \\
\text { important }\end{array}$ & $\begin{array}{l}\text { Quite } \\
\text { important }\end{array}$ & $\begin{array}{l}\text { Not very } \\
\text { important }\end{array}$ & $\begin{array}{l}\text { Not at all } \\
\text { important }\end{array}$ & $\begin{array}{l}\text { Don't } \\
\text { know }\end{array}$ \\
\hline $\begin{array}{l}\text { Fee too high/ too } \\
\text { expensive }\end{array}$ & 8 & 22 & 23 & 35 & 12 \\
\hline $\begin{array}{l}\text { People doing my job just } \\
\text { don't join }\end{array}$ & 7 & 21 & 33 & 34 & 5 \\
\hline $\begin{array}{l}\text { Union does not achieve } \\
\text { anything I value }\end{array}$ & 10 & 29 & 31 & 21 & 10 \\
\hline $\begin{array}{l}\text { I get all the benefits } \\
\text { anyway }\end{array}$ & 12 & 22 & 31 & 24 & 11 \\
\hline
\end{tabular}

Source: BWRPS Q42. N=239

\section{Panel B: Spearman's rank correlation coefficients}

\begin{tabular}{|l|l|l|l|l|}
\hline & Fees too high & $\begin{array}{l}\text { People in my } \\
\text { job just don't } \\
\text { join }\end{array}$ & $\begin{array}{l}\text { Union doesn't } \\
\text { achieve } \\
\text { anything }\end{array}$ & $\begin{array}{l}\text { I get all the } \\
\text { benefits } \\
\text { anyway }\end{array}$ \\
\hline Fees too high & 1.00 & - & - & - \\
\hline $\begin{array}{l}\text { People in my } \\
\text { job just don't } \\
\text { join }\end{array}$ & $\begin{array}{l}.165 \\
(.017)\end{array}$ & 1.00 & - & - \\
\hline $\begin{array}{l}\text { Union doesn't } \\
\text { achieve } \\
\text { anything }\end{array}$ & $\begin{array}{l}.237 \\
(.001)\end{array}$ & $\begin{array}{l}.332 \\
(.000)\end{array}$ & 1.00 & - \\
\hline $\begin{array}{l}\text { Iget all the } \\
\text { benefits } \\
\text { anyway }\end{array}$ & $\begin{array}{l}.240 \\
(.001)\end{array}$ & $\begin{array}{l}.316 \\
(.000)\end{array}$ & $\begin{array}{l}.263 \\
(.000)\end{array}$ & 1.00 \\
\hline
\end{tabular}

Source: BWRPS Q42. Spearman's rank rho correlation coefficients for respondents other than those replying 'don't know'. Statistical significance of correlation in parentheses 
Table 4: Marginal Effects, free-riding in Britain and New Zealand, pooled

\begin{tabular}{|c|c|c|c|c|c|}
\hline & (1) & (2) & (3) & $(4)$ & (5) \\
\hline $\begin{array}{l}\text { Mean predicted value of being a non- } \\
\text { member }\end{array}$ & 0.37 & 0.37 & 0.35 & 0.37 & 0.37 \\
\hline \multirow[t]{2}{*}{ New Zealand (ref.: Britain) } & 0.15 & 0.15 & 0.21 & 0.13 & 0.17 \\
\hline & $(3.14)^{\star \star \star}$ & $(3.07)^{\star \star \star}$ & $(4.05)^{\star \star \star}$ & $(2.70)^{\star \star \star}$ & $(3.21)^{\star \star \star}$ \\
\hline \multicolumn{6}{|l|}{ Age (ref.: aged $35-44$ years) } \\
\hline \multirow[t]{2}{*}{$15-24$ years } & 0.24 & 0.23 & 0.26 & 0.24 & 0.25 \\
\hline & $(3.29)^{\star \star \star}$ & $(3.18)^{\star \star \star}$ & $(3.49)^{\star \star \star}$ & $(3.34)^{\star \star \star}$ & $(3.37)^{\star \star \star}$ \\
\hline \multirow[t]{2}{*}{$25-34$ years } & 0.10 & 0.10 & 0.10 & 0.09 & 0.09 \\
\hline & $(1.99)^{\star *}$ & $(2.00)^{\star \star}$ & $(1.92)^{*}$ & $(1.79)^{*}$ & $(1.85)^{*}$ \\
\hline \multicolumn{6}{|l|}{ Hours (ref.: $30-40$ hours) } \\
\hline \multirow[t]{2}{*}{$<30$} & 0.15 & 0.15 & 0.15 & 0.17 & 0.15 \\
\hline & $(2.85)^{\star \star \star}$ & $(2.68)^{\star \star *}$ & $(2.55)^{\star \star}$ & $(3.07)^{\star \star \star}$ & $(2.46)^{\star \star}$ \\
\hline \multirow[t]{2}{*}{$>40$} & -0.11 & -0.11 & -0.12 & -0.11 & -0.11 \\
\hline & $(2.75)^{\star \star \star}$ & $(2.63)^{\star \star \star}$ & $(2.89)^{\star \star \star}$ & $(2.54)^{\star *}$ & $(2.58)^{\star \star \star}$ \\
\hline \multicolumn{6}{|l|}{$\begin{array}{l}\text { Tenure with employer (ref.: < } \\
\text { years) }\end{array}$} \\
\hline \multirow[t]{2}{*}{$10+$ years } & -0.11 & -0.09 & ns & -0.11 & $\mathrm{~ns}$ \\
\hline & $(1.94)^{\star}$ & $(1.66)^{*}$ & $(1.06)$ & $(1.98)^{\star *}$ & $(0.62)$ \\
\hline \multirow[t]{2}{*}{ Manager (ref.: non-manager) } & 0.10 & 0.09 & ns & 0.11 & ns \\
\hline & $(1.69)^{*}$ & $(1.66)^{*}$ & $(1.36)$ & $(1.95)^{\star}$ & (1.41) \\
\hline \multicolumn{6}{|l|}{ Pay (ref.: low) } \\
\hline \multirow[t]{2}{*}{ Medium } & -0.12 & -0.12 & -0.12 & -0.13 & -0.12 \\
\hline & $(2.28)^{* \star}$ & $(2.23)^{\star *}$ & $(2.16)^{\star \star}$ & $(2.34)^{\star *}$ & $(2.11)^{* *}$ \\
\hline \multirow[t]{2}{*}{ High } & -0.15 & -0.15 & -0.17 & -0.16 & -0.18 \\
\hline & $(2.24)^{* \star}$ & $(2.26)^{\star *}$ & $(2.57)^{\star \star}$ & $(2.44)^{* *}$ & $(2.63)^{\star \star \star}$ \\
\hline \multirow[t]{2}{*}{ Public sector (ref.: private) } & -0.17 & -0.18 & -0.16 & -0.16 & -0.15 \\
\hline & $(4.20)^{\star \star \star}$ & $(4.21)^{\star * *}$ & $(3.74)^{\star \star \star}$ & $(3.94)^{\star * \star}$ & $(3.53)^{\star \star \star}$ \\
\hline \multirow{2}{*}{$\begin{array}{l}\text { Organzation with } 1000+\text { employees } \\
\text { (ref: }<1,000)\end{array}$} & -0.13 & -0.13 & -0.10 & -0.13 & -0.08 \\
\hline & $(3.31)^{\star \star \star}$ & $(3.18)^{\star \star \star}$ & $(2.31)^{\star \star}$ & $(3.17)^{\star \star \star}$ & $(1.85)^{*}$ \\
\hline \multirow[t]{2}{*}{ Needs scale } & & -0.01 & & & -0.03 \\
\hline & & $(1.90)^{*}$ & & & $(3.74)^{\star \star \star}$ \\
\hline \multirow[t]{2}{*}{ Union effectiveness scale } & & & -0.04 & & -0.05 \\
\hline & & & $(4.73)^{\star \star \star}$ & & $(5.13)^{\star \star \star}$ \\
\hline \multirow{2}{*}{$\begin{array}{l}\text { Workplace would be worse without } \\
\text { union (ref.: would be better/no } \\
\text { different) }\end{array}$} & & & -0.31 & & -0.29 \\
\hline & & & $(8.60)^{\star \star *}$ & & $(8.11)^{\star \star \star}$ \\
\hline \multicolumn{6}{|l|}{$\begin{array}{l}\text { Perceptions of management } \\
\text { attitudes towards unions (ref.: } \\
\text { opposed) }\end{array}$} \\
\hline \multirow[t]{2}{*}{ In favour } & & & & -0.17 & -0.17 \\
\hline & & & & $(3.07)^{\star \star \star}$ & $(2.94)^{\star \star \star}$ \\
\hline \multirow[t]{2}{*}{ Neutral } & & & & ns & -0.11 \\
\hline & & & & $(0.42)$ & $(1.90)^{*}$ \\
\hline
\end{tabular}

Notes:

(1) Full models are reported in the Data Appendix.

(2) $\mathrm{N}=1,088$

(3) Coefficients are marginal effects estimated at the mean weighted values for the estimation sample. T-statistics are presented in parentheses. ${ }^{*}=$ significant at $90 \%$ level. $* *=$ significant at $95 \%$ level $* * *=$ significant at $99 \%$ level.

(4) The actual weighted mean for non-membership in the estimation sample is 0.38 . 
Table 5: Marginal Effects, free-riding, separate country models

\begin{tabular}{|c|c|c|c|c|}
\hline & (1) NZ & (2) Britain & (3) NZ & (4) Britain \\
\hline Mean predicted value of being a non-member & 0.46 & 0.32 & 0.45 & 0.28 \\
\hline \multirow{2}{*}{ Male (ref.: female) } & 0.17 & -0.08 & 0.25 & ns \\
\hline & $(2.48)^{\star \star}$ & $(1.86)^{*}$ & $(3.40)^{\star \star \star}$ & $(1.09)$ \\
\hline \multicolumn{5}{|l|}{ Age (ref.: $35-44$ years) } \\
\hline \multirow[t]{2}{*}{ 15-24 years } & 0.28 & 0.20 & 0.32 & 0.20 \\
\hline & $(2.08)^{* *}$ & $(2.44)^{* *}$ & $(2.34)^{\star *}$ & $(2.40)^{* *}$ \\
\hline \multirow[t]{2}{*}{$25-34$ years } & 0.22 & ns & 0.22 & ns \\
\hline & $(2.54)^{\star *}$ & (1.11) & $(2.38)^{\star *}$ & $(0.90)$ \\
\hline \multirow[t]{2}{*}{ Non-white (ref.: white) } & -0.13 & -0.13 & ns & ns \\
\hline & $(1.67)^{\star}$ & $(1.70)^{*}$ & $(1.42)$ & $(1.53)$ \\
\hline \multicolumn{5}{|l|}{ Qualifications (ref.: low) } \\
\hline \multirow[t]{2}{*}{ Medium } & ns & ns & ns & ns \\
\hline & $(0.76)$ & $(0.29)$ & $(0.14)$ & $(0.25)$ \\
\hline \multirow[t]{2}{*}{ High } & ns & ns & ns & 0.12 \\
\hline & $(1.05)$ & $(0.95)$ & $(0.17)$ & $(1.89)^{*}$ \\
\hline \multicolumn{5}{|l|}{ Hours (ref.: $30-40$ ) } \\
\hline \multirow[t]{2}{*}{$<30$} & 0.19 & 0.15 & ns & 0.19 \\
\hline & $(1.78)^{*}$ & $(2.42)^{\star \star}$ & $(0.03)$ & $(2.85)^{\star \star \star *}$ \\
\hline \multirow[t]{2}{*}{$>40$} & -0.17 & -0.09 & -0.20 & -0.09 \\
\hline & $(2.37)^{\star \star}$ & $(1.74)^{*}$ & $(2.52)^{\star \star}$ & $(1.73)^{*}$ \\
\hline \multirow[t]{2}{*}{$10+$ years tenure (ref.: $<2$ years) } & ns & -0.15 & ns & -0.10 \\
\hline & $(0.64)$ & $(2.50)^{\star *}$ & $(0.24)$ & $(1.61)^{\star}$ \\
\hline \multirow[t]{2}{*}{ Career job (ref.: not part of long-term career) } & ns & ns & -0.16 & ns \\
\hline & $(1.16)$ & $(0.70)$ & $(1.86)^{*}$ & $(0.89)$ \\
\hline \multirow[t]{2}{*}{ Manager (ref.: non-manager) } & 0.19 & 0.19 & 0.18 & 0.17 \\
\hline & $(2.07)^{\star \star}$ & $(2.18)^{\star \star}$ & $(1.61)^{*}$ & $(2.07)^{\star \star}$ \\
\hline \multirow[t]{2}{*}{ Supervisor (ref.: not supervisor) } & 0.15 & ns & ns & -0.08 \\
\hline & $(2.09)^{\star \star}$ & (1.35) & $(1.18)$ & $(1.82)^{*}$ \\
\hline \multicolumn{5}{|l|}{ Pay (ref.: low) } \\
\hline \multirow[t]{2}{*}{ Medium } & ns & $-0.11^{*}$ & ns & ns \\
\hline & $(0.51)$ & $(1.80)$ & (1.11) & (1.41) \\
\hline \multirow[t]{2}{*}{ High } & ns & -0.12 & ns & -0.13 \\
\hline & $(0.82)$ & $(1.63)^{*}$ & (1.38) & $(1.78)^{*}$ \\
\hline \multirow[t]{2}{*}{ Public sector (ref.: private) } & -0.23 & -0.16 & -0.19 & -0.14 \\
\hline & $(2.81)^{\star \star *}$ & $(3.34)^{\star \star *}$ & $(2.40)^{\star *}$ & $(3.02)^{* \star *}$ \\
\hline \multirow[t]{2}{*}{ Organization with $1000+$ employees (ref.: $<1,000$ ) } & ns & -0.15 & ns & -0.08 \\
\hline & $(1.36)$ & $(3.19)^{\star * *}$ & (1.21) & $(1.79)^{\star}$ \\
\hline \multirow[t]{2}{*}{ Needs scale } & & & -0.04 & -0.03 \\
\hline & & & $(2.67)^{\star \star \star}$ & $(3.09)^{\star \star *}$ \\
\hline \multicolumn{5}{|l|}{ Perceived management attitudes to unions (ref.: opposition) } \\
\hline In favour & & & ns & -0.14 \\
\hline & & & $(1.55)$ & $(1.98)^{\star *}$ \\
\hline Neutral & & & ns & ns \\
\hline & & & $(1.34)$ & $(0.98)$ \\
\hline Union effectiveness scale & & & -0.07 & -0.04 \\
\hline & & & $(3.73)^{\star \star \star}$ & $(4.00)^{\star \star \star}$ \\
\hline $\begin{array}{l}\text { Workplace would be worse without union (ref.: would be } \\
\text { better/no different) }\end{array}$ & & & -0.39 & -0.24 \\
\hline & & & $(5.68)^{\star \star \star}$ & $(5.60)^{\star \star *}$ \\
\hline
\end{tabular}

Notes:

(1) Full models are reported in the Data Appendix.

(2) $\mathrm{N}=646$ for British models and 442 for New Zealand models.

(3) Coefficients are marginal effects estimated at the mean weighted values for the estimation sample. T-

statistics are presented in parentheses. ${ }^{*}=$ significant at $90 \%$ level. ${ }^{*}=$ significant at $95 \%$ level $* *=$ significant at $99 \%$ level.

(4) The actual weighted mean for non-membership is 35\% Britain and 45\% New Zealand. 


\section{Data Appendix}

\section{'Baseline' control variables}

The baseline characteristics that are identical in the two surveys are: sex, age, hours worked (usual weekly including overtime or extra hours), employer tenure, career job, and organizational size.

In BWRPS managers are 'managers and senior administrators' whereas, in NZWRPS they are 'managers or professionals in a position requiring a university degree'. Supervisors are those answering 'yes' to the question: 'As an official part of your (main) job, do you supervise the work of other employees or tell other employees what to do?' The NZWRPS measure is identical but uses the phrase 'supervise or manage' in place of 'supervise'. The broader questions in NZWRPS explain the higher incidence of managers and supervisors in New Zealand compared with Britain.

The 'white' group in New Zealand is 'New Zealand European/Pakeha'; in Britain it's 'white'.

The questions relating to qualifications are not comparable, so we construct measures of 'low', 'medium' and 'high' qualifications. In BWRPS, employees are asked for their 'highest educational qualification'. 'Low' includes qualifications up to GCSE-level, including no qualifications; 'medium' is A-level or equivalent and 'high' is degree of post-graduate degree-level. The 'Other' qualifications category is subsumed into the 'low' qualifications category in the multivariate analyses. In NZWRPS, employees are asked for their 'highest level of education'. 'Low' qualifications are those below $6^{\text {th }}$ Form Certificate; 'medium' includes $6^{\text {th }}$ Form Certificate, a 'bursary or equivalent', 'technical or trade certificate' and 'tertiary diploma'. 'High' includes degrees and post-graduate degrees.

BWRPS asks employees for their gross pay per week or year using twelve bands. 'Low' pay is defined as under $£ 201$ per week; 'medium' pay is $£ 201-£ 400$ per week; 'high' pay is over $£ 400$ per week. NZWRPS, on the other hand, asks for 'total personal income before tax'. This is labelled 'pay' for convenience, with 'low' pay being up to $\$ 20,000$ per annum; 'medium' being $\$ 20,000$ up to $\$ 40,000$ per annum, and 'high' being $\$ 40,000$ per annum and above.

Neither data set contains a public sector identifier. In BWRPS 'public' is proxied by a dummy variable scoring ' 1 ' if the industry is 'Public Administration, Civil Service or Defence', 'Education', 'Health and Social Work' or 'Community, Social and Personal Services or Membership Organizations'. In NZWRPS, 'public' is proxied by the dummy industry variable scoring ' 1 ' if the industry is 'Government Administration and Defence', 'Education', 'Health and Social Work' or 'Community, Social and Personal Services'.

\section{Index of 'needs'}

This additive index, which is identical in both surveys, counts one point for each of the following: every time a respondent gave management a $\mathrm{D}$ or $\mathrm{F}$ grade in relation to 'promoting equal opportunities for women and ethnic minorities', 'understanding and knowledge of the business', 'keeping everyone up to date with proposed changes', 'concern for employees', 'willingness to share power and authority with employees in the workplace', 'making work interesting and enjoyable', 'giving fair pay increases and bonuses'. A point was also added each time respondents disagreed with the statements 'managers here are understanding about employees having to meet family responsibilities', 'people here are encouraged to develop their skills', and 'my job is secure in this workplace'. A point was also added when employees rated management-employee relations as 'poor', they did not 'trust your employer to keep its promises to you and other employees... at all', and when they were not satisfied with their 'influence...in company decisions that affect your job or work life'. 


\section{Substitutes}

Three substitutes measured in both surveys are three dummy variables indicating the presence of 'a personnel or Human Resources department' (NZWRPS refers to a 'department or person'), an 'open door policy so employees can tell senior management about problems with their supervisors', and the presence of a 'committee of management and employees who meet regularly to consult over workplace issues'.

The policies only available in BWRPS are: 'a formal grievance procedure' and five nonstandard forms of payment, namely 'payments or bonuses related to the profits made by your employer', 'an employee share ownership scheme', a 'save-as-you-earn (SAYE) scheme', 'individual or group performance-related pay' and 'any other cash bonuses'.

The policies only available in NZWRPS are: 'regular meetings with all staff'; 'a committee of employees that discusses problems with management on a regular basis' and 'an employee involvement program such as quality circles'.

\section{Employee perceptions of management attitudes to unionization}

The BWRPS measure uses responses to the question: 'How would you rate the attitude of your management at your workplace towards unions (or similar bodies). Are your managers...in favour of unions, neutral about unions, or opposed to trade unions?'

The NZWRPS uses responses to the question: 'Would you say managers are...in favour of unions, neutral about unions, or opposed to unions?'

\section{Union instrumentality}

In BWRPS, unions scored ' 1 ' every time they were viewed as 'excellent' or 'good' on each of six items:

- 'winning fair pay increases and bonuses'

- 'understanding and knowledge of your employer's business'

- 'being open and accountable to its members'

- 'working with management to increase quality or productivity'

- 'making work interesting and enjoyable'

- 'protecting workers against unfair treatment'.

The second measure of union instrumentality in BWRPS is a dummy variable scoring ' 1 ' when respondents answered 'a little worse' or 'a lot worse' to the question: 'Do you think your workplace would be a better or worse place to work if there was no union or would it make no difference?'

The NZWRPS additive scale is constructed using measures identical to those constructed for BWRPS except that the quality/productivity item uses the word 'improve' instead of 'increase'.

The NWRPS dummy variable on the difference union removal would make is similar to the BWRPS measure, except the question relates to 'you personally' instead of 'your workplace'.

\section{Ideology}

For BWRPS, ideological orientation towards unions was measured with two variables. The first, is a dummy variable scoring ' 1 ' where respondents 'strongly agree' with the statement 'Strong trade unions are needed to protect the working conditions and wages of employees'. The second is a dummy scoring ' 1 ' where respondents 'strongly disagree' with the statement 
'trade unions are old fashioned' or 'trade unions have no future in modern Britain', depending on to which of these two statements they were randomly assigned.

The NZWRPS measure of ideology is based on factor analysis of five political attitude statements:

- 'management always tries to get the better of employees'

- 'big business benefits owners at the expense of employees'

- 'there is one law for the rich and another for the poor'

- 'ordinary working people don't get a fair share of the nation's wealth'

- 'government should redistribute wealth from the rich to the poor'.

Responses were coded on a 5-point scale from 'strongly agree' to 'strongly disagree'. They are used to construct a 'left-right' index which positions individuals on a political spectrum from left to right. Principal components analysis revealed a factor with an eigenvalue of 2.4 accounting for 47 percent of variance in responses to the five questions. Standardizing the items, the average inter-item correlation is 0.33 and the Cronbach's alpha scale reliability coefficient is 0.71 . The scale runs from -1.34 to 1.67 , with lower scores indicating more 'left-wing'. 
Appendix Table A1: Mean scores for independent variables used in multivariate analyses

\begin{tabular}{|c|c|c|}
\hline & Britain & New Zealand \\
\hline Men & 53 & 53 \\
\hline \multicolumn{3}{|l|}{ Age (years): } \\
\hline $15-24$ & 11 & 5 \\
\hline $25-34$ & 27 & 19 \\
\hline $35-44$ & 28 & 32 \\
\hline 45-54 & 24 & 25 \\
\hline $55+$ & 10 & 19 \\
\hline \multicolumn{3}{|l|}{ Ethnicity: } \\
\hline Non-white & 6 & 20 \\
\hline \multicolumn{3}{|l|}{ Qualifications: } \\
\hline Low & 45 & 31 \\
\hline Middle & 19 & 38 \\
\hline High & 31 & 32 \\
\hline Other & 5 & NA \\
\hline \multicolumn{3}{|l|}{ Hours worked: } \\
\hline$<30$ & 18 & 14 \\
\hline $30-40$ & 52 & 42 \\
\hline$>\mathbf{4 0}$ & 30 & 44 \\
\hline \multicolumn{3}{|l|}{ Tenure with employer: } \\
\hline$<2$ years & 16 & 16 \\
\hline 2-4 years & 27 & 28 \\
\hline 5-9 years & 17 & 22 \\
\hline $10+$ years & 40 & 34 \\
\hline Career job & 77 & 69 \\
\hline Manager & 8 & 31 \\
\hline Supervisor & 42 & 59 \\
\hline \multicolumn{3}{|l|}{ Pay: } \\
\hline Low & 23 & 12 \\
\hline Middle & 40 & 42 \\
\hline High & 29 & 44 \\
\hline DK/refused & 7 & 1 \\
\hline Public sector & 49 & 44 \\
\hline $\begin{array}{l}\text { Organizational size: } \\
<=1,000 \text { employees }\end{array}$ & 23 & 40 \\
\hline
\end{tabular}




\begin{tabular}{|c|c|c|}
\hline $\begin{array}{l}>1,000 \text { employees } \\
\text { DK size }\end{array}$ & $\begin{array}{l}73 \\
4 \\
\end{array}$ & $\begin{array}{l}34 \\
26\end{array}$ \\
\hline Needs & 2.4 & 2.1 \\
\hline Workplace worse without union & 54 & 54 \\
\hline Union effectiveness score & 2.8 & 3.4 \\
\hline $\begin{array}{l}\text { Management attitudes: } \\
\text { Favours union } \\
\text { Neutral } \\
\text { Opposes union } \\
\text { Don't know }\end{array}$ & $\begin{array}{l}41 \\
44 \\
10 \\
5\end{array}$ & $\begin{array}{l}31 \\
38 \\
24 \\
7\end{array}$ \\
\hline $\begin{array}{l}\text { Substitutes: } \\
\text { HR department } \\
\text { Open door } \\
\text { JCC }\end{array}$ & $\begin{array}{l}54 \\
58 \\
67\end{array}$ & $\begin{array}{l}70 \\
85 \\
61\end{array}$ \\
\hline Variables only available in one of & untri & \\
\hline $\begin{array}{l}\text { Need strong union: } \\
\text { Yes }\end{array}$ & 51 & NA \\
\hline $\begin{array}{l}\text { Trade union modern } \\
\text { Yes }\end{array}$ & 36 & NA \\
\hline $\begin{array}{l}\text { Union density at the workplace: } \\
\text { Almost all/all } \\
\text { A clear majority } \\
\text { About half } \\
\text { A small minority } \\
\text { Almost none } \\
\text { Don't know }\end{array}$ & NA & $\begin{array}{l}29 \\
22 \\
17 \\
16 \\
7 \\
9 \\
\end{array}$ \\
\hline $\begin{array}{l}\text { Left-right scale quartiles: } \\
\text { Bottom quartile } \\
\text { Second quartile } \\
\text { Third quartile } \\
\text { Top quartile } \\
\end{array}$ & NA & $\begin{array}{l}30 \\
24 \\
22 \\
24 \\
\end{array}$ \\
\hline $\begin{array}{l}\text { Union substitutes: } \\
\text { Grievance procedure } \\
\text { Profit-related pay } \\
\text { ESOP } \\
\text { SAYE } \\
\text { Performance-related pay } \\
\text { Cash bonuses }\end{array}$ & $\begin{array}{l}54 \\
22 \\
12 \\
9 \\
10 \\
11 \\
\end{array}$ & $\begin{array}{l}\text { NA } \\
\text { NA } \\
\text { NA } \\
\text { NA } \\
\text { NA } \\
\text { NA }\end{array}$ \\
\hline
\end{tabular}




\begin{tabular}{|l|l|l|}
\hline DK about performance pay & $<1$ & NA \\
Regular meetings with management & NA & 63 \\
Employee committee & NA & 55 \\
EI program & NA & 42 \\
\hline
\end{tabular}

Notes:

(1) Unweighted $\mathrm{N}=1,088,646$ British, 442 New Zealanders.

(2) Figures are weighted with survey weights. This explains why the distribution of the 'leftright' scale quartiles are not evenly distributed.

(3) Details of data derivation are given in the Data Appendix. 
Appendix Table A2: Full probit models for free-riding, pooled

\begin{tabular}{|c|c|c|c|c|c|c|c|c|c|}
\hline & (1) & (2) & (3) & (4) & (5) & (6) & (7) & (8) & (9) \\
\hline \multirow[t]{2}{*}{$\mathrm{NZ}$} & 0.391 & 0.383 & 0.549 & 0.561 & 0.392 & 0.380 & 0.338 & 0.459 & 0.477 \\
\hline & $(3.14)^{* *}$ & $(3.07)^{\star *}$ & $(4.05)^{\star *}$ & $(4.18)^{\star *}$ & $(3.05)^{* *}$ & $(2.91)^{\star *}$ & $(2.70)^{\star *}$ & $(3.21)^{\star *}$ & $(3.36)^{* *}$ \\
\hline \multirow[t]{2}{*}{ Male } & 0.021 & 0.043 & 0.087 & 0.088 & 0.021 & 0.019 & 0.022 & 0.113 & 0.109 \\
\hline & $(0.20)$ & $(0.41)$ & $(0.77)$ & $(0.77)$ & $(0.19)$ & $(0.17)$ & $(0.21)$ & $(1.02)$ & $(0.98)$ \\
\hline \multirow[t]{2}{*}{ Age 1524} & 0.599 & 0.579 & 0.665 & 0.650 & 0.599 & 0.599 & 0.612 & 0.644 & 0.636 \\
\hline & $(3.29)^{\star *}$ & $(3.18)^{\star \star}$ & \begin{tabular}{|l}
$(3.49)^{\star *}$ \\
\end{tabular} & $(3.42)^{\star *}$ & $(3.29)^{\star *}$ & $(3.28)^{\star *}$ & $(3.34)^{\star *}$ & $(3.37)^{\star \star}$ & $(3.33)^{\star \star}$ \\
\hline \multirow{2}{*}{ Age 2534} & 0.257 & 0.259 & 0.258 & 0.243 & 0.257 & 0.260 & 0.233 & 0.251 & 0.233 \\
\hline & $(1.99)^{\star}$ & $(2.00)^{*}$ & $(1.92)$ & $(1.82)$ & $(1.99)^{*}$ & $(2.03)^{\star}$ & $(1.79)$ & $(1.85)$ & $\begin{array}{l}(1.73) \\
\end{array}$ \\
\hline \multirow[t]{2}{*}{ Age 4554} & 0.089 & 0.107 & 0.031 & 0.021 & 0.089 & 0.088 & 0.115 & 0.072 & 0.059 \\
\hline & $(0.69)$ & $(0.83)$ & $(0.23)$ & $(0.16)$ & $(0.69)$ & $(0.68)$ & $(0.88)$ & $(0.53)$ & $(0.44)$ \\
\hline \multirow[t]{2}{*}{ Age 55+ } & -0.087 & -0.094 & $\begin{array}{l}-0.094 \\
\end{array}$ & -0.098 & -0.087 & -0.090 & -0.063 & -0.104 & -0.116 \\
\hline & $(0.57)$ & $(0.63)$ & $(0.59)$ & $(0.61)$ & $(0.57)$ & $(0.59)$ & $(0.42)$ & $(0.64)$ & $(0.72)$ \\
\hline \multirow[t]{2}{*}{ Ethnic } & -0.242 & -0.251 & -0.178 & -0.195 & -0.241 & -0.237 & -0.284 & -0.214 & -0.227 \\
\hline & (1.51) & $(1.53)$ & $(1.02)$ & $(1.14)$ & $(1.50)$ & $(1.48)$ & $\begin{array}{l}(1.73) \\
\end{array}$ & $(1.20)$ & $(1.29)$ \\
\hline \multirow[t]{2}{*}{ Ed Mid } & -0.023 & -0.022 & \begin{tabular}{|l|}
-0.015 \\
\end{tabular} & 0.024 & -0.023 & -0.019 & 0.016 & 0.041 & 0.073 \\
\hline & $(0.18)$ & $(0.18)$ & $(0.11)$ & $(0.18)$ & $(0.18)$ & $(0.15)$ & $(0.13)$ & $\begin{array}{l}(0.31) \\
\end{array}$ & $(0.55)$ \\
\hline \multirow[t]{2}{*}{ Ed High } & 0.030 & 0.019 & 0.200 & 0.234 & 0.031 & 0.045 & 0.095 & 0.239 & 0.268 \\
\hline & $\begin{array}{l}(0.22) \\
\end{array}$ & $(0.14)$ & (1.36) & $(1.62)$ & $\begin{array}{l}(0.22) \\
\end{array}$ & $(0.33)$ & $(0.69)$ & $\begin{array}{l}(1.62) \\
\end{array}$ & $\begin{array}{l}(1.83) \\
\end{array}$ \\
\hline \multirow[t]{2}{*}{$\mathrm{Hrs}<30$} & 0.395 & 0.373 & 0.399 & 0.390 & 0.396 & 0.383 & 0.428 & 0.385 & 0.380 \\
\hline & $(2.85)^{* \star}$ & $(2.68)^{\star \star}$ & $(2.55)^{\star}$ & $(2.49)^{*}$ & $(2.85)^{\star \star}$ & $(2.74)^{\star *}$ & $(3.07)^{* *}$ & $(2.46)^{*}$ & $(2.41)^{*}$ \\
\hline \multirow[t]{2}{*}{ Hrs $>40$} & -0.309 & -0.299 & \begin{tabular}{|l|l|}
-0.336 \\
\end{tabular} & -0.354 & -0.309 & -0.313 & -0.290 & -0.306 & -0.322 \\
\hline & $(2.75)^{\star \star}$ & $(2.63)^{\star \star}$ & $(2.89)^{\star \star}$ & $(3.05)^{\star *}$ & $(2.75)^{\star \star}$ & $(2.77)^{\star \star}$ & $(2.54)^{*}$ & $(2.58)^{\star \star}$ & $(2.73)^{\star \star}$ \\
\hline \multirow{2}{*}{ Tenure 2-4 } & 0.015 & 0.045 & 0.094 & 0.131 & 0.015 & 0.016 & 0.015 & 0.146 & 0.178 \\
\hline & $(0.11)$ & $(0.32)$ & $(0.63)$ & $(0.87)$ & $\begin{array}{l}(0.11) \\
\end{array}$ & $(0.12)$ & $(0.11)$ & $(0.95)$ & $(1.16)$ \\
\hline \multirow[t]{2}{*}{ Tenure5-9 } & -0.080 & -0.038 & 0.005 & 0.044 & -0.080 & -0.075 & -0.077 & 0.080 & 0.115 \\
\hline & $(0.50)$ & $(0.24)$ & $(0.03)$ & $(0.26)$ & $\begin{array}{l}(0.50) \\
\end{array}$ & $(0.47)$ & $(0.48)$ & $\begin{array}{l}(0.46) \\
\end{array}$ & $(0.65)$ \\
\hline \multirow{2}{*}{ Tenure10+ } & -0.291 & -0.251 & \begin{tabular}{|l|}
-0.176 \\
\end{tabular} & -0.153 & -0.290 & -0.279 & -0.301 & -0.106 & -0.081 \\
\hline & $(1.94)$ & $(1.66)$ & $(1.06)$ & $(0.92)$ & $(1.93)$ & $(1.83)$ & $(1.98)^{*}$ & $(0.62)$ & $(0.47)$ \\
\hline \multirow[t]{2}{*}{ Career } & 0.001 & -0.056 & 0.050 & 0.045 & 0.001 & -0.012 & 0.040 & -0.041 & -0.039 \\
\hline & $(0.00)$ & $(0.46)$ & $(0.40)$ & $(0.37)$ & $(0.01)$ & $(0.10)$ & $(0.34)$ & $(0.33)$ & $(0.32)$ \\
\hline \multirow[t]{2}{*}{ Manager } & 0.246 & 0.240 & 0.203 & 0.224 & 0.246 & 0.256 & 0.283 & 0.210 & 0.228 \\
\hline & $\begin{array}{l}(1.69) \\
\end{array}$ & $(1.66)$ & $(1.36)$ & $(1.51)$ & $\begin{array}{l}(1.70) \\
\end{array}$ & $\begin{array}{l}(1.77) \\
\end{array}$ & $\begin{array}{l}(1.95) \\
\end{array}$ & $\begin{array}{l}(1.41) \\
\end{array}$ & $\begin{array}{l}(1.53) \\
\end{array}$ \\
\hline Supervisor & 0.081 & 0.069 & 0.029 & 0.016 & 0.081 & 0.066 & 0.099 & 0.006 & -0.003 \\
\hline & $(0.79)$ & $(0.67)$ & $(0.26)$ & $(0.14)$ & $(0.79)$ & $(0.64)$ & $(0.97)$ & $(0.05)$ & $(0.02)$ \\
\hline Pay Mid & -0.326 & -0.320 & -0.331 & -0.327 & -0.325 & -0.321 & -0.338 & -0.328 & -0.330 \\
\hline & $(2.28)^{*}$ & $(2.23)^{*}$ & $(2.16)^{*}$ & $(2.11)^{\star}$ & $(2.27)^{*}$ & $(2.24)^{*}$ & $(2.34)^{*}$ & $(2.11)^{*}$ & $(2.10)^{*}$ \\
\hline Pay $\mathrm{Hi}$ & -0.400 & -0.405 & -0.485 & -0.441 & -0.400 & -0.390 & -0.440 & -0.501 & -0.466 \\
\hline & $(2.24)^{*}$ & $(2.26)^{*}$ & $(2.57)^{*}$ & $(2.32)^{*}$ & $(2.23)^{*}$ & $(2.17)^{*}$ & $(2.44)^{*}$ & $(2.63)^{\star \star}$ & $(2.43)^{*}$ \\
\hline Pay DK & 0.001 & -0.025 & \begin{tabular}{|l|}
-0.139 \\
\end{tabular} & -0.179 & 0.001 & 0.015 & -0.053 & -0.224 & -0.275 \\
\hline & $(0.00)$ & $(0.12)$ & $(0.58)$ & $(0.73)$ & $(0.01)$ & $(0.07)$ & $(0.25)$ & $(0.94)$ & (1.14) \\
\hline Public & -0.469 & -0.472 & \begin{tabular}{|l|}
-0.432 \\
\end{tabular} & -0.440 & -0.469 & -0.470 & -0.441 & -0.408 & -0.419 \\
\hline & $(4.20)^{\star *}$ & $(4.21)^{\star \star}$ & $(3.74)^{\star \star}$ & $(3.81)^{\star *}$ & $(4.20)^{\star *}$ & $(4.21)^{\star \star}$ & $(3.94)^{\star \star}$ & $(3.53)^{\star *}$ & $(3.63)^{\star *}$ \\
\hline Size $1000+$ & -0.358 & -0.344 & -0.260 & -0.228 & -0.357 & -0.343 & -0.343 & -0.213 & -0.182 \\
\hline & $(3.31)^{\star \star}$ & $(3.18)^{\star \star}$ & $(2.31)^{\star}$ & $(2.03)^{\star}$ & $(3.26)^{\star \star}$ & $(3.12)^{\star \star}$ & $(3.17)^{\star \star}$ & (1.85) & $(1.60)$ \\
\hline Size DK & -0.611 & -0.611 & \begin{tabular}{|l|}
-0.522 \\
\end{tabular} & -0.537 & -0.611 & -0.607 & -0.605 & -0.495 & -0.512 \\
\hline & $(3.60)^{* \star}$ & $(3.56)^{\star \star}$ & $(2.94)^{\star \star}$ & $(3.06)^{\star *}$ & $(3.58)^{\star *}$ & $(3.58)^{\star \star}$ & $(3.53)^{\star \star}$ & $(2.76)^{\star \star}$ & $(2.87)^{\star \star}$ \\
\hline Needs & & -0.034 & & & & & & -0.075 & -0.075 \\
\hline & & $(1.90)$ & & & & & & $(3.74)^{\star *}$ & $(3.80)^{\star *}$ \\
\hline Union & & & \begin{tabular}{|l|}
-0.119 \\
\end{tabular} & & & & & -0.136 & \\
\hline & & & $(4.73)^{\star *}$ & & & & & $(5.13)^{* *}$ & \\
\hline Man fav. & & & & & & & -0.460 & -0.483 & -0.487 \\
\hline & & & & & & & $(3.07)^{\star \star}$ & $(2.94)^{\star \star}$ & $(3.03)^{\star \star}$ \\
\hline Man neut. & & & & & & & -0.061 & -0.288 & -0.284 \\
\hline & & & & & & & $(0.42)$ & $(1.90)$ & (1.93) \\
\hline Man DK & & & & & & & 0.209 & -0.026 & -0.044 \\
\hline & & & & & & & $(0.89)$ & $(0.11)$ & $(0.19)$ \\
\hline
\end{tabular}




\begin{tabular}{|l|l|l|l|l|l|l|l|l|l|}
\hline Hr Dept & & & & & & -0.068 & & -0.003 & -0.002 \\
\hline & & & & & & $(0.67)$ & & $(0.03)$ & $(0.02)$ \\
\hline Open door & & & & & & 0.091 & & 0.043 & 0.037 \\
\hline & & & & & & $(0.86)$ & & $(0.38)$ & $(0.33)$ \\
\hline Jcc & & & & & & -0.015 & & -0.040 & -0.056 \\
\hline & & & & & & $(0.15)$ & & $(0.38)$ & $(0.53)$ \\
\hline Get worse & & & -0.856 & -0.831 & & & & -0.801 & -0.778 \\
\hline & & & $(8.60)^{* *}$ & $(8.46)^{* *}$ & & & & $(8.11)^{* *}$ & $(7.91)^{* *}$ \\
\hline Substitutes & & & & & -0.002 & & & & \\
\hline & & & & & $(0.04)$ & & & & \\
\hline Constant & 0.250 & 0.331 & 0.762 & 0.780 & 0.252 & 0.236 & 0.360 & 1.222 & 1.255 \\
\hline & $(1.11)$ & $(1.44)$ & $(3.19)^{* *}$ & $(3.28)^{* *}$ & $(1.08)$ & $(1.01)$ & $(1.42)$ & $(4.22)^{* *}$ & $(4.36)^{* *}$ \\
\hline Observations & 1088 & 1088 & 1088 & 1088 & 1088 & 1088 & 1088 & 1088 & 1088 \\
\hline
\end{tabular}

Notes. (1) Probit coefficients with t-stats in parentheses. $*=$ sig at $95 \%$; $* *=\operatorname{sig}$ at $99 \%$ (2) Reference categories are: Britain; Female; aged 35-44; non-white; low education; 30-40 hours; $<2$ years tenure; not career job; non-manager; not supervisor; low pay; organization $<1 \mathrm{k}$ employees; management opposed to union; no HR department; no open door; no JCC; same/better without union. 
Appendix Table A3: Full probit models for free-riding, separate country models

\begin{tabular}{|c|c|c|c|c|}
\hline & (1) NZ & (2) $\mathrm{Br}$ & (11) NZ & (12) $\mathrm{Br}$ \\
\hline \multirow[t]{2}{*}{ Male } & 0.442 & -0.248 & 0.642 & -0.150 \\
\hline & $(2.48)^{*}$ & $(1.86)$ & $(3.40)^{\star \star}$ & $(1.09)$ \\
\hline \multirow[t]{2}{*}{ Age 1524} & 0.730 & 0.521 & 0.853 & 0.540 \\
\hline & $(2.08)^{*}$ & $(2.44)^{*}$ & $(2.34)^{*}$ & $(2.40)^{*}$ \\
\hline \multirow[t]{2}{*}{ Age 2534} & 0.549 & 0.178 & 0.580 & 0.148 \\
\hline & $(2.54)^{\star}$ & (1.11) & $(2.38)^{*}$ & $(0.90)$ \\
\hline \multirow[t]{2}{*}{ Age 4554} & 0.117 & 0.126 & 0.013 & 0.118 \\
\hline & $(0.56)$ & $(0.79)$ & $(0.06)$ & $(0.69)$ \\
\hline \multirow[t]{2}{*}{ Age 55+ } & 0.072 & -0.108 & -0.015 & -0.065 \\
\hline & $(0.31)$ & $(0.56)$ & $(0.06)$ & $(0.31)$ \\
\hline \multirow[t]{2}{*}{ Ethnic } & -0.344 & -0.400 & -0.338 & -0.398 \\
\hline & (1.67) & $(1.70)$ & (1.42) & (1.53) \\
\hline \multirow[t]{2}{*}{ Ed Mid } & -0.160 & 0.047 & 0.034 & 0.043 \\
\hline & $(0.76)$ & $(0.29)$ & $(0.14)$ & $(0.25)$ \\
\hline \multirow[t]{2}{*}{ Ed High } & -0.282 & 0.154 & 0.055 & 0.330 \\
\hline & $(1.05)$ & $(0.95)$ & $(0.17)$ & $(1.89)$ \\
\hline \multirow[t]{2}{*}{$\mathrm{Hrs}<30$} & 0.487 & 0.398 & -0.010 & 0.512 \\
\hline & $\begin{array}{l}(1.78) \\
\end{array}$ & $(2.42)^{*}$ & $(0.03)$ & $(2.85)^{\star \star}$ \\
\hline \multirow[t]{2}{*}{$\mathrm{Hrs}>40$} & -0.438 & -0.252 & -0.509 & -0.263 \\
\hline & $(2.37)^{\star}$ & $(1.74)$ & $(2.52)^{*}$ & (1.73) \\
\hline \multirow[t]{2}{*}{ Tenure 2-4 } & 0.189 & -0.096 & 0.291 & 0.019 \\
\hline & $(0.78)$ & $(0.56)$ & $(1.03)$ & $(0.11)$ \\
\hline \multirow{2}{*}{ Tenure5-9 } & 0.110 & -0.234 & 0.243 & -0.126 \\
\hline & $(0.42)$ & $(1.19)$ & $(0.77)$ & $(0.60)$ \\
\hline \multirow[t]{2}{*}{ Tenure10+ } & -0.169 & -0.449 & 0.076 & -0.315 \\
\hline & $(0.64)$ & $(2.50)^{\star}$ & $(0.24)$ & (1.61) \\
\hline \multirow[t]{2}{*}{ Career } & -0.240 & 0.097 & -0.403 & 0.130 \\
\hline & $(1.16)$ & $(0.70)$ & $(1.86)$ & $(0.89)$ \\
\hline \multirow[t]{2}{*}{ Manager } & 0.482 & 0.499 & 0.443 & 0.472 \\
\hline & $(2.07)^{\star}$ & $(2.18)^{*}$ & $(1.61)$ & $(2.07)^{\star}$ \\
\hline \multirow[t]{2}{*}{ Supervisor } & 0.368 & -0.173 & 0.240 & -0.245 \\
\hline & $(2.09)^{*}$ & $(1.35)$ & (1.18) & $(1.82)$ \\
\hline \multirow{2}{*}{ Pay Mid } & -0.148 & -0.303 & -0.345 & -0.260 \\
\hline & $(0.51)$ & $(1.80)$ & (1.11) & (1.41) \\
\hline \multirow[t]{2}{*}{ Pay Hi } & -0.286 & -0.356 & -0.519 & -0.414 \\
\hline & $(0.82)$ & (1.63) & $(1.38)$ & $(1.78)$ \\
\hline Pay DK & 0.200 & 0.050 & -0.253 & -0.107 \\
\hline & $\begin{array}{l}(0.33) \\
\end{array}$ & $\begin{array}{l}(0.22) \\
\end{array}$ & (0.38) & $(0.41)$ \\
\hline Public & -0.584 & -0.443 & -0.493 & -0.417 \\
\hline & $(2.81)^{\star \star}$ & $(3.34)^{\star *}$ & $(2.40)^{*}$ & $(3.02)^{\star \star}$ \\
\hline Size $1000+$ & -0.274 & -0.416 & -0.267 & -0.244 \\
\hline & $(1.36)$ & $(3.19)^{\star *}$ & $(1.21)$ & $(1.79)$ \\
\hline Size DK & -0.636 & -0.633 & -0.440 & -0.726 \\
\hline & $(3.19)^{\star *}$ & $(2.24)^{*}$ & $(2.14)^{*}$ & $(2.34)^{*}$ \\
\hline Needs & & & -0.101 & -0.077 \\
\hline & & & $(2.67)^{\star \star}$ & $(3.09)^{* *}$ \\
\hline Man fav. & & & -0.402 & -0.436 \\
\hline & & & $(1.55)$ & $(1.98)^{*}$ \\
\hline Man neut. & & & -0.304 & -0.198 \\
\hline & & & $(1.34)$ & $(0.98)$ \\
\hline Man DK & & & 0.221 & -0.032 \\
\hline & & & $(0.58)$ & $(0.10)$ \\
\hline Union effectiveness & & & -0.183 & -0.130 \\
\hline & & & $(3.73)^{\star \star}$ & $(4.00)^{* *}$ \\
\hline Get worse & & & -1.010 & -0.702 \\
\hline & & & $(5.68)^{\star *}$ & $(5.60)^{\star *}$ \\
\hline HR department & & & -0.158 & 0.073 \\
\hline
\end{tabular}




\begin{tabular}{|l|l|l|l|l|}
\hline & & & $(0.79)$ & $(0.58)$ \\
\hline Open door & & & -0.089 & 0.059 \\
\hline JCC & & & $(0.37)$ & $(0.47)$ \\
\hline & & & 0.112 & -0.084 \\
\hline Constant & & & $(0.62)$ & $(0.65)$ \\
\hline & 0.224 & 0.482 & 1.915 & 1.261 \\
\hline Observations & $(0.53)$ & $(1.82)$ & $(3.41)^{\star *}$ & $(3.69)^{\star *}$ \\
\hline
\end{tabular}

Notes. (1) Probit coefficients with t-stats in parentheses. $*=\operatorname{sig}$ at $95 \%$; $*=\operatorname{sig}$ at $99 \%$ (2) Reference categories are: Female; aged 35-44; non-white; low education; 30-40 hours; $<2$ years tenure; not career job; non-manager; not supervisor; low pay; organization $<1 \mathrm{k}$ employees; management opposed to union; no HR department; no open door; no JCC; same/better without union. 


\section{CENTRE FOR ECONOMIC PERFORMANCE Recent Discussion Papers}

712 Marco Manacorda Carolina Sanchez-Paramo Norbert Schady

711 Claudia Olivetti Barbara Petrongolo

710 Hilary Steedman

709 Florence Kondylis

708 David Metcalf Jianwei Li

707 Richard Walker

706 Miklós Koren Silvana Tenreyro

705 Andy Charlwood

704 Michael W. L. Elsby

703 David Marsden Richard Belfield

702 John Van Reenen

701 Joas Santos Silva Silvana Tenreyro

700 Alan Manning Joanna Swaffield
Changes in Returns to Education in Latin America: the Role of Demand and Supply of Skills

Unequal Pay or Unequal Employment? A CrossCountry Analysis of Gender Gaps

Apprenticeship in Europe: 'Fading' or Flourishing?

Agicultural Returns and Conflict: Quasi-Experimental Evidence from a Policy Intervention Programme in Rwanda

Chinese Unions: Nugatory or Transforming? An Alice Analysis

Superstars and Renaissance Men: Specialization, Market Size and the Income Distribution

Volatility and Development

The De-Collectivisation of Pay Setting in Britain 1990-1998: Incidence, Determinants and Impact

Evaluating the Economic Significance of Downward Nominal Wage Rigidity

Performance Pay for Teachers Linking Individual and Organisational Level Targets

The Growth of Network Computing: Quality Adjusted Price Changes for Network Servers

The Log of Gravity

The Gender Gap in Early Career Wage Growth 
697 Alan Manning

696 Andrew B. Bernard Stephen Redding Peter K. Schott

695 Henry G. Overman Anthony J. Venables

694 Carlo Rosa Giovanni Verga

693 Richard Dickens Mirko Draca

692 Ralf Martin

691 Augustin de Coulon François-Charles Wolff

690 Monika Merz Eran Yashiv

689 Pierre-Philippe Combes Giles Duranton Henry G. Overman

688 Stephen Redding Daniel M. Sturm

687 Vicente Cuñat Maria Guadalupe
You Can't Always Get What You Want: the Impact of the Jobseeker's Allowance

Factor Price Equality and the Economies of the United States

Cities in the Developing World

The Importance of the Wording of the ECB

The Employment Effects of the October 2003

Increase in the National Minimum Wage

Computing the True Spread

Immigrants at Retirement: Stay/Return or 'Va-etVient'?

Labor and the Market Value of the Firm

Agglomeration and the Adjustment of the Spatial Economy

The Costs of Remoteness: Evidence from German Division and Reunification

How Does Product Market Competition Shape Incentive Contracts?

The Centre for Economic Performance Publications Unit Tel 02079557673 Fax $02079557595 \quad$ Email info@cep.lse.ac.uk Web site http://cep.lse.ac.uk 